\title{
Promising Perspectives for Detection, Identification, and Quantification of Plant Pathogenic Fungi and Oomycetes through Targeting Mitochondrial DNA
}

\author{
Tomasz Kulik*(D), Katarzyna Bilska® and Maciej Żelechowski® \\ Department of Botany and Nature Protection, University of Warmia and Mazury in Olsztyn, Plac Łódzki 1, \\ 10-727 Olsztyn, Poland; katarzyna.bilska@uwm.edu.pl (K.B.); maciej.zelechowski92@gmail.com (M.Z.) \\ * Correspondence: tomaszkulik76@gmail.com
}

Received: 20 March 2020; Accepted: 9 April 2020; Published: 10 April 2020

\begin{abstract}
Fungi and oomycetes encompass many pathogens affecting crops worldwide. Their effective control requires screening pathogens across the local and international trade networks along with the monitoring of pathogen inocula in the field. Fundamentals to all of these concerns are their efficient detection, identification, and quantification. The use of molecular markers showed the best promise in the field of plant pathogen diagnostics. However, despite the unquestionable benefits of DNA-based methods, two significant limitations are associated with their use. The first limitation concerns the insufficient level of sensitivity due to the very low and uneven distribution of pathogens in plant material. The second limitation pertains to the inability of widely used diagnostic assays to detect cryptic species. Targeting mtDNA appears to provide a solution to these challenges. Its high copy number in microbial cells makes mtDNA an attractive target for developing highly sensitive assays. In addition, previous studies on different pathogen taxa indicated that mitogenome sequence variation could improve cryptic species delimitation accuracy. This review sheds light on the potential application of mtDNA for pathogen diagnostics. This paper covers a brief description of qPCR and DNA barcoding as two major strategies enabling the diagnostics of plant pathogenic fungi and oomycetes. Both strategies are discussed along with the potential use of mtDNA, including their strengths and weaknesses.
\end{abstract}

Keywords: plant pathogenic fungi and oomycetes; detection; identification; quantification; DNA-based markers; mitochondrial DNA

\section{Introduction}

Fungi and oomycetes include a large number of pathogens having an enormous impact on the production and quality of food, fiber and biofuel crops worldwide [1-4]. Both groups of microorganisms belong to different phyla but are morphologically similar, exhibit filamentous growth and an osmotrophic lifestyle $[5,6]$.

From about 100,000 described fungal species, around $20 \%$ comprise plant pathogens responsible for $70-80 \%$ of plant diseases $[7,8]$. Among the top ten fungal species/complexes of worldwide scientific and economic importance [9], seven: Magnaporthe oryzae, Puccinia spp., Fusarium graminearum sensu stricto (s.s.), Blumeria graminis, Zymoseptoria tritici (formerly Mycosphaerella graminicola), Ustilago maydis, and Melampsora lini are associated with cereals. A high priority cereal pathogen can also encompass Rhizoctonia solani causing sheath blight and yield reduction in rice and other crops [9].

Their importance is underscored by the fact that more than one-half of the world's daily caloric intake is derived directly from cereal grain consumption [10]. Other highly destructive plant pathogens include Botrytis cinerea, the causal agent of gray mold on a wide range of fruit and vegetables [11], 
Fusarium oxysporum species complex (FOSC), responsible for vascular wilt diseases of economically important crops [12], Colletotrichum spp., causing anthracnose on more than 30 plant genera [13] and Phakopsora pachyrhizi, the causal agent of Asian soybean rust [9].

Besides yield reductions, many plant pathogenic as well as spoilage fungi create a considerable qualitative loss of food and feed by contamination of plant material with mycotoxins [14,15]. The genera of mycotoxigenic fungi are mainly represented by Aspergillus, Penicillium, and Fusarium [16]. Mycotoxins produced by these fungi have well-documented negative effects on humans and animals [17].

Oomycetes are the second major group of eukaryotic pathogens causing plant diseases. The most economically important pathogens include Phytophthora species, such as the potato late blight Phytophthora infestans [3,18,19], Phytophthora sojae which rots the roots of soybeans, Phytophthora capsici a devastating pathogen of vegetable crops, and P. cinnamomi attacking a wide range of plant species around the world including both oaks and chestnuts [20]. Other destructive species include P. palmivora, causing cocoa black pod, and P. ramorum, causing extensive damage and death to trees $[3,21]$. Moreover, economically important oomycete pathogens include members of the genus Pythium and downy mildews $[3,22,23]$.

Unlike typical saprotrophic microorganisms, many plant pathogenic species appear not to be driven by dispersal limitation or climate [24,25]. Plant pathogens can spread by a variety of means. In fungi, both asexual and sexual spores can disperse in large quantities by airflow and raindrops releasing millions of tons of spores into the atmosphere every year [26]. However, recently, the increase in foodstuff trade has been recognized as the most significant risk factor contributing to the introduction of invasive plant pathogens into new locations $[1,27,28]$. Therefore, the control of plant pathogens requires biosecurity and quarantine systems in international trade to minimize their spread [4]. The eight fungal species/complexes of the highest importance [9] are: Magnaporthe oryzae, Botrytis cinerea, Fusarium graminearum s.s., Fusarium oxysporum species complex, Zymoseptoria tritici, Colletotrichum species complex, Melampsora lini, and Rhizoctonia solani that can spread through transported plant material [25,29-32].

To date, however, the most striking negative consequences of the spread of invasive pathogens can be derived from the introduction of plant pathogenic oomycetes which have caused damage to crops, ornamental plants, and forests on a global scale for centuries [33]. The most destructive oomycetes Phytophthora infestans, Phytophthora palmivora, Phytophthora ramorum, and Plasmopara obducens together with their pathology, importance and impact are extensively discussed in Brasier (2008) [33] and Derevnina et al. (2016) [3]. It is now generally accepted that their success in invading new geographic areas results from their potential to spread through the transport of infected or infested plant material or water, a flexible mating system, and their ability to adapt rapidly to new hosts and environments [3].

Besides international biosecurity regulatory mechanisms, the monitoring of the movement of pathogens across the plant trade network is crucial to reducing the spread of invasive pathogens [32]. In addition, the monitoring of pathogen inocula in the field is an important approach to provide continuously updated data on microbial surveillance and adaptation $[1,34]$.

A fundamental aspect to all of these concerns is the efficient identification of pathogens. Effective detection of pathogens provides all necessary data to undertake more predictive and preventative actions [4]. Such knowledge includes information on species, cryptic species, races, formae speciales, anastomosis groups, and mating types. However, the efficient detection of plant pathogens is still a challenging task. Microbial biomass may persist at relatively low levels as mycelium colonizing the tissue internally and/or spores infesting the surface of a given material, which cannot be often detectable by visual means. Notably, the methods applied to detect pathogen diversity should be of high sensitivity, reliability, and rapidity. In addition, today, it has become imperative to effectively detect morphologically indistinguishable cryptic species within fungal complexes [35,36].

Among the number of diagnostic methods for fungi and oomycetes, molecular identification (DNA-based) showed the best promise in the field of plant pathogen diagnostics. However, despite the unquestionable benefits of DNA-based methods, two significant limitations are associated with its 
use. The first limitation concerns the insufficient level of sensitivity of diagnostic assays, which is mainly associated with targeting single-copy nuclear genes. The second major limitation pertains to the inability of widely used diagnostic assays to detect cryptic species.

This review aims to provide the potential application of mitochondrial DNA (mtDNA) in the field of eukaryotic plant pathogen detection. Our paper covers brief descriptions of two major strategies enabling both quantification and identification of plant pathogenic fungi and oomycetes. The first one involves qPCR technology for pathogen detection/quantification, and the second one describes DNA barcoding for identification of fungi and oomycetes to the species level. Both strategies are discussed along with the potential use of mtDNA including their strengths and weaknesses.

\section{A Brief Overview of qPCR for the Detection and Quantification of Plant Pathogenic Fungi and Oomycetes}

The taxonomy provides a basic understanding of fungal biodiversity which is necessary for effective plant disease management. Undoubtedly, taxonomic information is essential in communicating between scientists, the regulatory authorities and related organizations $[37,38]$. Traditional taxonomic research allows for the identification of morphologically different fungal species. However, time-consuming and laborious culture-based methods have frequently been criticized by mycologists mostly due to difficulties in the culturing of some species, and the inability to quantify the pathogens [39-41].

Molecular approaches have led to greater confidence and accuracy in the identification of plant pathogenic fungi and oomycetes [39,42,43]. The most prevalent molecular method relies upon polymerase chain reaction (PCR), which has long been used in the field of plant pathology [44-47]. The major advantage of PCR over older traditional methods is the abortion of laborious and time-consuming culturing of microorganisms $[39,47]$. Microbial templates used for PCR may be extracted from diseased plant material or samples from contaminated habitats such as soil, water, or air [47-50]. The high reliability of PCR is mainly achieved by the incorporation of specific primers, which prevent undesired amplification [51]. By choosing appropriate primers, it is possible to target different species [52,53], races [54,55], formae speciales [56-59], and genotypes [60-62]. Many different PCR-based assays for diagnosis and monitoring of plant pathogens have been extensively reviewed in Singh and Gupta (2017) [63].

The other remarkable advantage of PCR is its high sensitivity. Even very low concentrations of pathogen DNA present in a complex DNA mixture could be effectively amplified and visualized. The major limitation of conventional PCR results from the requirement of time-consuming gel electrophoresis with visualization, which is not optimal for the detection of trace quantities of DNA due to its lower sensitivity [64]. In addition, the high risk of carry-over amplicons from previous amplification has been the main impediment to using PCR routinely in diagnostic laboratories [65-67]. More importantly, like other minor molecular techniques such as loop-mediated isothermal amplification (LAMP) [68] and dot blot hybridization [69], conventional PCR does not provide quantitative data $[70,71]$.

When it comes to quantification of microbes, real-time PCR (syn. qPCR (quantitative PCR) is a major breakthrough revolutionizing plant pathology for more than two decades. Real-time PCR enables the monitoring of fluorescent signal which is proportional to the amount of amplicon produced in each cycle and can be generated by an intercalating dye or from the breakdown of a dye-labeled probe during amplification [72,73]. This allows the detection and quantification of specific DNA molecules either for their presence or absence or for their amount [74].

The major advantages of real-time PCR are: ease-of-use, closed-tube format, rapidity, simplicity to perform analysis, and the extremely wide dynamic range of quantification (more than eight orders of magnitude) [75]. Notably, compared to endpoint PCR, real-time PCR technology is more sensitive due to a fluorescent marker [76,77]. In addition, the use of hydrolysis probes (TaqMan) offers an additional level of specificity [77]. 
Most qPCR-based approaches for plant pathogens have been designed to detect and quantify traditionally defined species (Tables 1 and 2).

Table 1. Examples of species-specific quantitative polymerase chain reaction (qPCR) approaches for morphologically defined plant pathogenic fungi and oomycetes of the highest scientific and economic importance $([9,20])$.

\begin{tabular}{|c|c|c|c|c|}
\hline Species & DNA Target & $\begin{array}{l}\text { Real-Time } \\
\text { Format }\end{array}$ & LOD (Limit of Detection) & References \\
\hline \multicolumn{5}{|c|}{ Plant Pathogenic Fungi } \\
\hline Magnaporthe oryzae & 18S-28S rDNA & SybrGreen & $\begin{array}{l}0.069 \mathrm{pg} \text { of genomic DNA } \\
\text { extracted from fungal culture }\end{array}$ & [78] \\
\hline \multirow{4}{*}{ Botrytis cinerea } & IGS & TaqMan & $\begin{array}{l}0.02 \mathrm{pg} \text { of genomic DNA extracted } \\
\text { from fungal culture and from } \\
\text { infected plant material }\end{array}$ & [79] \\
\hline & IGS & SybrGreen & $\begin{array}{l}6.3 \mathrm{pg} \text { of genomic DNA extracted } \\
\text { from fungal culture }\end{array}$ & {$[80]$} \\
\hline & $R P B 2$ & EvaGreen & $\begin{array}{c}1.55 \text { pg from infected plant } \\
\text { material }\end{array}$ & [81] \\
\hline & Cutinase A & SybrGreen & $\begin{array}{l}0.2 \text { pg genomic DNA extracted } \\
\text { from fungal culture }\end{array}$ & {$[79,82]$} \\
\hline F. culmorum & $\begin{array}{l}\text { Mitochondrial } \\
\text { Cox } 2\end{array}$ & TaqMan & $\begin{array}{l}0.005-0.05 \text { pg of genomic DNA } \\
\text { extracted from fungal culture }\end{array}$ & [83] \\
\hline \multirow{2}{*}{ Fusarium graminearum } & $T E F-1 \alpha$ & SybrGreen & $\begin{array}{l}0.1 \text { pg genomic DNA extracted } \\
\text { from fungal culture }\end{array}$ & [84] \\
\hline & Anonymous & TaqMan & $\begin{array}{l}0.09 \mathrm{pg} \text { genomic DNA extracted } \\
\text { from fungal culture }\end{array}$ & [85] \\
\hline F. oxysporum & TEF-1 $\alpha$ & SybrGreen & $\begin{array}{l}1 \text { pg of genomic DNA extracted } \\
\text { from fungal culture }\end{array}$ & [86] \\
\hline \multirow[b]{2}{*}{$\begin{array}{c}\text { Zymoseptoria tritici } \\
\text { (former Mycosphaerella } \\
\text { graminicola) }\end{array}$} & rDNA & SybrGreen & $\begin{array}{c}1 \text { pg of DNA extracted from } \\
\text { infected leaf samples }\end{array}$ & [87] \\
\hline & $\begin{array}{l}\text { microsatellite } \\
\text { repeats }\end{array}$ & SybrGreen & $\begin{array}{l}0.01 \mathrm{pg} \text { of genomic DNA extracted } \\
\text { from fungal culture } \\
0.05 \text { pg of DNA extracted from } \\
\text { infected leaf samples }\end{array}$ & [88] \\
\hline \multirow{2}{*}{ Colletotrichumacutatum } & ITS1 rDNA & TaqMan & $\begin{array}{l}0.05 \mathrm{pg} \text { of genomic DNA extracted } \\
\text { from fungal culture and } 12 \mathrm{pg} \text { per } \\
100 \mathrm{mg} \text { plant material. }\end{array}$ & [89] \\
\hline & ITS rDNA & SybrGreen & $\begin{array}{l}0.02 \mathrm{pg} \text { from infected plant } \\
\text { samples }\end{array}$ & {$[90]$} \\
\hline \multicolumn{5}{|c|}{ Plant Pathogenic Oomycetes } \\
\hline \multirow[t]{2}{*}{ Phytophthora infestans } & ITS rDNA & TaqMan & $\begin{array}{l}0.1 \text { pg extracted from pure } \\
\text { cultures of } P \text {. infestans }\end{array}$ & {$[91]$} \\
\hline & ITS rDNA & SybrGreen & $0.5 \mathrm{pg} / \mu \mathrm{L}$ & [92] \\
\hline $\begin{array}{l}\text { Hyaloperonospora } \\
\text { arabidopsidis }\end{array}$ & $\begin{array}{l}\text { single-copy } \\
\text { Hpa gene }\end{array}$ & SybrGreen & not determined & [93] \\
\hline \multirow{3}{*}{ Phytophthora ramorum } & ITS rDNA & SybrGreen & $\begin{array}{l}0.012 \mathrm{pg} \text { of genomic DNA } \\
\text { extracted from pathogen biomass }\end{array}$ & [94] \\
\hline & $\begin{array}{l}\text { IGS between Cox } \\
\text { II and Cox I }\end{array}$ & TaqMan & $\begin{array}{l}0.001 \mathrm{pg} \text { of genomic DNA } \\
\text { extracted from pathogen biomass }\end{array}$ & [95] \\
\hline & Ypt1 & $\begin{array}{c}\text { TaqMan } \\
\text { (multiplex) }\end{array}$ & $\begin{array}{l}0.1 \text { pg of genomic DNA extracted } \\
\text { from pathogen biomass }\end{array}$ & [96] \\
\hline \multirow[t]{2}{*}{ Phytophthora sojae } & ITS rDNA & SybrGreen & $\begin{array}{l}1 \mathrm{pg} \text { of genomic DNA extracted } \\
\text { from pathogen biomass }\end{array}$ & [97] \\
\hline & ITS rDNA & SybrGreen & $\begin{array}{c}0.001 \mathrm{pg} / \mu \mathrm{L} \text { of genomic DNA } \\
\text { extracted from pathogen biomass }\end{array}$ & [98] \\
\hline Phytophthora capsici & ITS rDNA & SybrGreen & $\begin{array}{l}0.01 \mathrm{pg} \text { of genomic DNA extracted } \\
\text { from pathogen biomass }\end{array}$ & [99] \\
\hline Plasmopara viticola & ITS rDNA & TaqMan & $\begin{array}{l}0.1 \text { pg of genomic DNA extracted } \\
\text { from pathogen biomass }\end{array}$ & {$[100]$} \\
\hline Phytophthora cinnamomi & $L P V$ & $\begin{array}{c}\text { SybrGreen } \\
\text { (nested PCR) }\end{array}$ & $\begin{array}{l}0.02 \mathrm{pg} \text { of genomic DNA extracted } \\
\text { from pure cultures of } P \text {. cinnamomi }\end{array}$ & [101] \\
\hline \multirow{2}{*}{ Pythium ultimum } & ITS rDNA & SybrGreen & $0.005 \mathrm{pg}$ from contaminated soil & [102] \\
\hline & ITS rDNA & SybrGreen & Not determined & [103] \\
\hline $\begin{array}{l}\text { Pythium ultimum var. } \\
\text { ultimum }\end{array}$ & ITS rDNA & SybrGreen & $\begin{array}{c}0.013 \mathrm{pg} \mu \mathrm{L}^{-1} \text { from infected plant } \\
\text { tissue }\end{array}$ & {$[104]$} \\
\hline
\end{tabular}


Table 2. Examples of qPCR approaches for cryptic species, formae speciales, and anastomosis groups of plant pathogenic fungi.

\begin{tabular}{|c|c|c|c|c|}
\hline Species & DNA Target & $\begin{array}{l}\text { Real-Time } \\
\text { Format }\end{array}$ & LOD (Limit of Detection) & References \\
\hline \multicolumn{5}{|c|}{ Cryptic Species } \\
\hline F. graminearum s.s. & MAT & TaqMan & $\begin{array}{c}0.64 \mathrm{pg} \text { of genomic DNA } \\
\text { extracted from fungal culture }\end{array}$ & [105] \\
\hline & Mitochondrial Cob & TaqMan & $\begin{array}{l}0.2-0.06 \mathrm{pg} \text { of genomic DNA } \\
\text { extracted from fungal culture }\end{array}$ & {$[53]$} \\
\hline $\begin{array}{l}\text { Colletotrichum } \\
\text { kahawae }\end{array}$ & GAPDH & TaqMan & $\begin{array}{l}0.08 \mathrm{pg} \mu \mathrm{L}^{-1} \text { of genomic DNA } \\
\text { extracted from fungal culture }\end{array}$ & [106] \\
\hline \multicolumn{5}{|c|}{ Formae Speciales } \\
\hline $\begin{array}{l}\text { F. oxysporum f. sp. } \\
\text { lycopersici }\end{array}$ & SIX1 & TaqMan & $\begin{array}{c}0.44 \mathrm{pg} \text { of genomic DNA } \\
\text { extracted from fungal culture }\end{array}$ & [107] \\
\hline \multirow{2}{*}{$\begin{array}{c}\text { F. oxysporum } \\
\text { f. sp. cubense race } 4\end{array}$} & Anonymous & SybrGreen & $\begin{array}{l}0.1 \mathrm{pg} \text { of genomic DNA } \\
\text { extracted from fungal culture }\end{array}$ & [108] \\
\hline & $\begin{array}{l}\text { Putative virulence } \\
\text { gene }\end{array}$ & TaqMan & $\begin{array}{l}24 \text { plasmid copies of target } \\
\text { DNA per reaction tube }\end{array}$ & [109] \\
\hline $\begin{array}{l}\text { F. oxysporumf. sp. } \\
\text { phaseoli }\end{array}$ & virulence factor $f t f 1$ & TaqMan & $\begin{array}{l}2 \mathrm{pg} \text { of genomic DNA } \\
\text { extracted from fungal culture }\end{array}$ & [110] \\
\hline $\begin{array}{l}\text { F. oxysporumf. sp. } \\
\text { spinaciae }\end{array}$ & IGS & TaqMan & $\begin{array}{c}0.01 \mathrm{pg} \text { of genomic DNA } \\
\text { extracted from fungal culture }\end{array}$ & [111] \\
\hline \multicolumn{5}{|c|}{ Anastomosis Groups } \\
\hline $\begin{array}{l}\text { Rhizoctonia solani } \\
\text { AG-1 IA }\end{array}$ & ITS rDNA & SybrGreen & $\begin{array}{c}1 \mathrm{pg} \text { of genomic DNA } \\
\text { extracted from fungal cultures }\end{array}$ & [112] \\
\hline $\begin{array}{l}\text { Rhizoctonia solani } \\
\text { AG-3 }\end{array}$ & ITS rDNA & TaqMan & $\begin{array}{c}0.006-0.009 \mathrm{pg} \text { DNA } \mu \mathrm{L}^{-1} \text { in } \\
\text { naturally contaminated soil }\end{array}$ & {$[76]$} \\
\hline
\end{tabular}

Among nuclear targets, ribosomal DNA (rDNA) containing protein-coding genes, introns, and intergenic spacers showed the best promise for plant pathogen quantification. The major advantages of targeting rDNA are: (i) simplicity to obtain the PCR products for sequencing due to established universal fungal primers, (ii) multi-copy nature offering increased amplification success of rDNA over single-copy targets, and (iii) additional ability to perform identification of species through sequence similarity searches against the large number of rDNA sequences in GenBank. Thus, it is not surprising that among 20 qPCR approaches for the most economically important plant pathogenic fungi, nearly half have been designed based on rDNA sequences (Table 1).

rDNA appears to have a higher resolving capacity for discriminating plant pathogenic oomycetes. Most of the diagnostic assays designed to detect and quantify this group of plant pathogens were developed based on rDNA.

Recently, many traditionally defined plant pathogenic fungal species have been found to be species complexes containing a large number of cryptic (syn. phylogenetic) species [113-117]. The most important examples of such economically significant complexes are: Colletotrichum acutatum, Colletotrichum gloeosporioides, F. graminearum, F. oxysporum, and Rhizoctonia solani. Deciphering cryptic species diversity appears to be critical for scientists to determine their geographical distribution and host range, to identify their biosafety and biosecurity threads, and to understand the evolution of pathogenicity $[4,113,118]$. Implementation of real-time technology for the diagnostics of phylogenetic species remains a considerable challenge mostly due to: (i) the need for initial screening of a large set of candidate genes to reveal a sufficient level of sequence polymorphism among closely related species and (ii) the continuous changes in fungal taxonomy which still undergo significant progress. Therefore, to date, only three different qPCR approaches have been designed to detect cryptic species among fungal plant pathogens (Table 2).

Ideal DNA targets for such assays cannot have non-orthologous copies. Thus, it appears that single-copy protein genes provide robust and reliable targets for successful detection of cryptic 
species within fungal complexes [119]. We hypothesize that the rapidly increasing progress in the sequencing of fungal genomes will accelerate the development of new quantitative assays through recognition of yet undescribed species and rapid detection of sequence polymorphisms to enable their quick differentiation.

Besides species determination, qPCR technology could be successfully used to study the genetic structures of field populations at the intraspecific level. For this purpose, numerous qPCR approaches have been designed to obtain additional genetic data regarding formae speciales [107,109], mating types [120,121], and mycotoxin genotypes [60,122].

Highly sensitive detection of pathogens is increasingly important. Pathogens may survive in environmental material or host DNA in relatively low quantities making their efficient detection challenging to analysts $[83,123]$. Microbial detection by any molecular method requires the use of extraction procedure that efficiently lyse cells and recovers DNA suitable for amplification. In general, difficulties in the detection of plant pathogens through PCR may be linked to either insufficient recovery of pathogen DNA for amplification or reduced limit of detection (LOD) of a given assay. Amongst plant pathogens, extraction of fungal DNA remains the most problematic mostly due to: (i) chitinous cell walls making cell lysis and DNA extraction inefficient [124], (ii) hyphal and patchy penetration of substrates (hyphae is difficult to concentrate by centrifugation) [125], and (iii) fungal spores can serve as an additional source of a DNA template for qPCR, however, some fungal genera such as Alternaria or Fusarium display reduced sporulation in relation to the growth of mycelia [126].

As shown in Tables 1 and 2, individual qPCR approaches designed to detect plant pathogenic fungi and oomycetes may largely differ in their detection limits. High differences can be found when comparing qPCR approaches for the same species and even targeting the same locus. A comparison of methodologies from various laboratories used to establish LOD values may provide some clues about these differences. First, the authors appear to use different cut-off values below which quantification cycle values $(\mathrm{Cq})$ indicate positive results [127]. This strategy allows to reduce the risk of false-positive results which may come from background noise. Secondly, it appears that LOD values are established using various criteria. Some authors establish LOD based on serial dilutions of genomic DNA extracted from pure pathogen biomass, while others define LOD as the lowest amount of genomic DNA that could be detectable from infected plant material or substrate. As shown by Martin et al. (2004) [128], LOD can significantly reduce when spiking target DNA with background DNA.

Finally, it appears that LOD values may also be affected by the type of real-time PCR format used to monitor the amplification process. For example, the widely used SybrGreen format has been found to be more sensitive than TaqMan [79], although the first one lacks consistently reproducible quantification when the target DNA is present in low quantities $[129,130]$. Samples exhibiting low pathogen load produce weak fluorescence signals resulting in high (or late) quantification cycle values (Cq). Detecting low copy template DNA is often error-prone mostly due to lower reproducibility of the results and the risk of late false-positive results generated by background noise [127]. To prevent it, the use of assays targeting repeated genomic sequences rather than the single copy gene assays is recommended [131,132]. The most commonly used methods utilizing multi-copy sequences are rDNA-based approaches. Dramatic differences in the detection limits of both rDNA and single-copy based assay were previously demonstrated by Suarez et al. (2005) [79]. Using the same biological samples, it was found that IGS-based (intergenic spacer) assay improved the detection limit of Botrytis cinerea by 1000-fold, as compared with single-copy cutinase-A assay [82].

However, despite the above benefit of utilizing rDNA, other significant diagnostic limitations are associated with its use. Some morphologically defined plant pathogenic fungi (e.g., Fusarium species) cannot be discriminated based on rDNA. In addition, the reduced discriminating power of rDNA limits recognition of morphologically indistinguishable cryptic species within the most economically important species complexes of plant pathogenic fungi. 


\section{A Brief Overview of DNA Barcoding for Identification of Plant Pathogenic Fungi and Oomycetes}

DNA barcoding is a relatively new method for identification of any species, which is now being applied to taxa across the tree of life, including fungi and oomycetes [133-138]. DNA barcode may be defined as a short, unique DNA sequence pattern (ca. 400-800 bp) which, in theory, can be quickly amplified, sequenced, and characterized by specific software to identify species $[4,139]$. In 2003, the DNA barcoding initiative began, searching to find a universal barcode for taxon identification [140]. The first proposed barcode was a mitochondrial cytochrome c oxidase subunit 1 (cox1, syn. co1) [140], tagging taxons in the animal kingdom. However, for barcoding of fungi, cox1 was excluded, mainly due to insufficient variation and mosaic distribution of introns, which bias amplification efficiency $[136,141,142]$. For the barcoding of fungi and oomycetes, the internal transcribed spacer (ITS) region has been proposed $[141,143,144]$. ITS is localized between the small-subunit ribosomal RNA (rRNA) and large-subunit rRNA genes in the chromosome. In eukaryotes, those genes occur in tandem repeats with thousands of copies, separated by regions of non-transcribed DNA named intergenic spacer (IGS) or non-transcribed spacer (NTS). ITS region appears to have the highest probability of reliable identification for fungi, with the most clearly defined barcode gap between inter- and intraspecific variation [143]. However, its broad utility as a species marker for fungi has been criticized, because: (i) divergent intragenomic ITS sequences are found in several fungal groups [145] and (ii) the low-resolution power in discriminating closely related species, including cryptic species [141,145]. Many plant pathogenic fungi, e.g., Alternaria, Botryosphaeria, Cercospora, Diaporthe, and Fusarium cannot be identified to the species level based on the ITS sequence $[141,146,147]$. In addition, in the downy mildew genera Basidiophora, Plasmopara, Plasmoverna, and relatives, the ITS region contains large insertions (often longer than $2 \mathrm{~kb}$ ) raising considerable difficulties in amplification and subsequent sequencing [148].

The ITS region also exhibits limitations in the discrimination of the species of oomycetes. In Phytophthora spp. [149-151] and Peronospora spp. [152,153], ITS regions show insufficient intraspecies variability for reliable determination of some species. In other economically important genera such as Bremia and Plasmopara of the Peronosporales, ITS regions contain long repetitive insertions, which largely limit amplification success of this barcode [148,152].

In fungi, other nuclear, single-copy protein-coding genes have been extensively tested for their efficacy in discrimination of plant pathogenic species. The most widely used genes include: the largest $(r p b 1)$ and the second-largest ( $r p b 2)$ subunits of RNA polymerase [154], translation elongation factor 1-alpha (tef1) [155-158], $\beta$-tubulin [159-161], the mini-chromosome maintenance protein $(\mathrm{mcm} 7)$ [162], calmodulin (CaM) [163], and topoisomerase I (top1) gene [164,165]. Notably, sequence polymorphisms of protein-coding genes offer an improved species resolution than ITS, although low amplification success often excludes them as candidates for routine barcoding of fungi [143].

It is worth noting, however, that reliable identification of cryptic species, which diverged relatively recently, requires more than one molecular marker. Thus, recognition of these masked species relies heavily on Genealogical Concordance Phylogenetic Species (GCPS), which involves multi-gene phylogenetic analyses [166-168]. Although GCPS seems to have profound implications for fungal control and quarantine [35], the requirement for multi-locus sequencing coupled to bioinformatic and phylogenetic analyses makes this method time-consuming and expertise specific. In addition, shortcomings related to decreased sensitivity of housekeeping genes largely limits the adoption of this method for environmental applications.

\section{Mitogenome Characteristics of Fungi and Oomycetes}

Most fungal lineages harbor mitochondria, the energy factories in eukaryotic cells. Besides energy production, mitochondria contribute to various cellular and organism functions [169-172] and can be involved in antifungal resistance, virulence and pathogenicity $[172,173]$. It is therefore not surprising 
that special attention has been drawn to study mitochondrial structure and function and its own genome (mitogenome) [170,174].

Nowadays, the relatively small size of fungal mitogenomes allows their robust study as an entity, especially with massively parallel sequencing platforms [175,176]. Currently, 653 fungal mitogenomes are available in the GenBank database with a large portion representing plant pathogenic species. Fungal mitogenomes vary widely in size, structure and in the content and order of their genes $[174,175,177]$. Most of them tend to be AT-rich and can exist in either linear or circular form [174]. Fungal mitogenomes range from 19 to over $200 \mathrm{kbs}$ [178,179], however fungi in the Neocallimastigales order have completely lost their mitochondrial genome [174]. Fungi can exhibit a diverse inheritance models: uniparental, biparental, and a mixture of both [180-183].

In general, fungal mitogenomes usually contain 14 protein-encoded genes: (i) atp6, atp8, atp9 (encoding subunits of ATP synthase), cob (encoding cytochrome b), cox1-3 (encoding cytochrome oxidase subunits), nad1-6, and nad4L (encoding the NADH dehydrogenase subunits), which are all implicated in oxidative phosphorylation and the production of ATP; (ii) two genes of rRNA ( $r n s$ and $r n l$ ) and a gene (rps3) are responsible for the translation and the composition of the small and large subunits of the mitochondrial ribosome; and (iii) a set of genes (trn) for tRNAs (ranging from 8-24) [174,177]. They also contain a variable number of self-splicing introns which are partial ribozymes. Group I introns typically found in fungi harbor homing endonucleases (HEGs) with LAGLIDADG and GIY-YIG motifs, which can promote their mobility among different lineages. Less common in fungi, group II introns usually contain reverse transcriptases. Homing endonucleases and transcriptases are selfish because they pose no obvious value to their host genomes [174,184-187].

Fungi exhibit remarkable variation in intron content [187], which can also be observed in plant pathogens. The Fusarium proliferatum mitogenome, for example, contains only a single intron [188], which is in contrast to R. solani which contains dozens of introns [179]. In addition, at the population or even strain level, these fungi can differ in intron content $[189,190]$. However, the same introns may also be found in evolutionarily distant lineages and their widespread distribution in fungi may be due to the intron-rich progenitor from which extensive intron loss has occurred [187,189]. In addition to intron loss, the infective nature of HEGs is believed to cause the observed variation in the intron content between different lineages. It should also be noted that exploration of the history of introns and associated HEGs across organisms is rather challenging for researchers, mostly because of the difficulty in detecting their gain and loss events in fungi $[189,191]$.

Currently, only 20 oomycete mitogenomes are available in the GenBank database with a significant portion representing plant pathogenic species. In this group of plant pathogens, both size and genetic structure of mitogenomes have been proven to be highly variable, from approximately $37 \mathrm{~kb}$ for Phytophthora infestans to the largest around $60 \mathrm{~kb}$ mitogenomes of Pythium spp. In contrast to fungi, mitogenomes of oomycetes lack introns, and the large inverted repeats which accumulate are the largest contributor to mitogenome size variation, especially in mitogenomes of Pythium spp. Yuan et al. (2017) [192] showed that the ancestral expansion of inverted repeats resulted in gene duplication in the Pythiales and Saprolegniales compared with the Peronosporales. It has been indicated that whole mitogenome analysis appears to provide a view of the evolutionary history and phylogeography of the oomycetes and a comparison of sequence data from herbaria and living organisms can detect evolutionary events leading to the divergence of this important group of pathogens [192,193].

\section{Targeting mtDNA Improves Detection and Quantification of Plant Pathogenic Fungi and Oomycetes}

The demand for highly sensitive detection of pathogens has become an important issue in recent years $[46,194]$. Targeting mtDNA seems an ideal solution, mainly due to the multi-copy nature of mtDNA in eukaryotic cells $[174,195,196]$.

Mitochondrial-based qPCR (mtqPCR) methods were developed and used to detect Aspergillus fumigatus in serum [197], bronchoalveolar lavage fluids, and tissue biopsy specimens [198]. 
The analytical sensitivity of the assay was one A. fumigatus conidium per reaction [198]. It has been demonstrated that mt-based detection of A. fumigatus in patients with risk factors for invasive aspergillosis showed lower LOD than other multi-copy rDNA assays [199].

For plant pathogens, the first mtqPCR approach was developed by Gao et al. (2004) [200] for both absolute and relative quantification of Fusarium virguliforme (formerly Fusarium solani f. sp. glycines) causing sudden death syndrome (SDS), a widespread and destructive soybean disease. The pathogen biomass was quantified utilizing the mitochondrial small subunit (mtSSU) rDNA region. The fungus was detected in soybean plants using SybrGreen format for contents as low as $9.0 \times 10^{-5} \mathrm{ng}$ in the absolute qPCR assays.

In another study, Li et al. (2008) [201] developed a TaqMan assay for the detection of F. virguliforme from soybean roots. A specific minor-groove binding (MGB) probe and primer set were derived from the sequences of the mtSSU. Unfortunately, the authors of the above study did not evaluate LOD and/or limit of quantification (LOQ) of the developed assay. A more recent study by Mbofung et al. (2011) [202] showed, however, that mtqPCR assays for F. virguliforme give positive results from the other SDS-causing Fusaria, as well as DNA from some F. solani strains. It is worth noting that these assays were developed prior to recent findings showing that the mtSSU locus is unable to resolve species boundaries within the SDS-bean root rot (BRR) clade of the F. solani species complex due to the conserved nature of this locus [202-204]. Unfortunately, to date, the GenBank database lacks complete mitogenome sequences from $F$. solani species complex, making it impossible to investigate which mitochondrial locus could be useful for reliable discrimination between various members of this complex.

Specific quantification of the cryptic species Fusarium graminearum s.s. using the mtqPCR approach has been recently demonstrated by Kulik et al. (2015) [53]. This ascomycete fungus is the major cause of Fusarium head blight (FHB), a devastating disease of small grain cereals worldwide. F. graminearum s.s. belongs to the monophyletic fungal complex referred to as F. graminearum species complex (FGSC) encompassing 16 cryptic species [205]. Primers and a MGB probe were designed utilizing sequence polymorphism within the intronic sequence of cob gene. The LOQ of the FgMito assay $(0.2 \mathrm{pg})$ is the equivalent of approximately five haploid cells of $F$. graminearum s.s, while the LOD of the assay was determined between 0.2 and $0.06 \mathrm{pg}$. The mean of these two concentrations equals approximately three haploid fungal cells. Comparison of FgMito assay with the assay targeting the nuclear genome [105] on naturally contaminated grains showed increased sensitivity of a mitochondrial-based approach in quantifying F. graminearum s.s.

In a more recent study, Bilska et al. (2018) [83] designed the mtqPCR approach for quantification of F. culmorum, a ubiquitous, soil-borne fungus causing foot and root rot and Fusarium head blight on cereals. Primers and MGB probe were designed based on the intronic sequence within the cox 2 gene. The LOQ of the FcMito assay was determined as $0.05 \mathrm{pg}$. This is 18 -fold lower than LOQ of another F. culmorum specific TaqMan assay targeting the nuclear genome [85]. The LOD of the new mitochondrial assay was determined between 0.05 and $0.005 \mathrm{pg}$, which corresponds to less than one and a quarter of the haploid cell of F. culmorum. This study also found a positive correlation between the F. culmorum mtDNA and the total trichothecenes present in naturally contaminated grains.

The use of mitochondrial DNA for quantification of oomycetes is more frequent than in fungi. It is worth noting that, in contrast to fungi, mitogenomes of oomycetes do not contain introns-making their prior amplification for sequencing and primer design easier.

One of the first mt-based assays for plant pathogenic oomycetes were developed for species that damage forests and trees. Tooley et al. (2006) [95] designed the primers and probes to quantify both pathogen (P. ramorum) and plant DNA in multiplex reactions enabling minimized underestimation of quantity and false negatives via PCR inhibition. The limit of detection of P. ramorum DNA was $1 \mathrm{fg}$ of genomic DNA, much lower than for many other described PCR procedures for detecting Phytophthora species. 
In another study, Martin et al. (2004) [128] designed the genus and species-specific markers targeting cox 1 and $\operatorname{cox} 2$ genes. Using DNA from purified cultures, the Phytophthora genus-specific primer pair successfully produced amplicon from all 45 Phytophthora spp. tested. Using purified pathogen DNA, the limit of detection for P. ramorum using this marker system was approximately $2.0 \mathrm{fg}$ of total DNA.

Bilodeau et al. (2014) [206] developed mitochondrial markers utilizing atp9 gene, intergenic spacer sequences and three tRNAs (trnM-trnP-trnM) to detect and quantify Phytophthora species. TaqMan markers encompassed genus-specific and species-specific assays for 13 species and the P. citricola species complex. The markers developed by Bilodeau et al. (2014) [206] were validated against a range of oomycetes from various geographic origins including: Phytophthora spp., Pythium spp., Phytopythium sp., as well as different plant DNA. Importantly, in silico analysis showed that species-specific assays could be developed for at least 70 other plant pathogenic oomycetes.

A more recent study by Yuan et al. (2017) [192] showed that among mitochondrial genes rpl6, rps10, atp8, nad11, rps11, rps2, rps3, nad9, and rps4 show similar resolution as rDNA and could be used for the identification of species in the Peronosporales. It has been suggested that the high sensitivity of mitochondrial markers can allow establishing more precise monitoring and control strategies for this group of important pathogens [192].

\section{Perspectives of Targeting mtDNA for Barcoding of Plant Pathogenic Fungi and Oomycetes}

In one of the first studies, Seifert et al. (2007) [142] demonstrated that a mitochondrial cox1 gene could be highly effective in the resolution of Penicillium species. The authors of the above paper designed primers that allowed generating amplicons from multiple strains encompassing 58 species of Penicillium subgenus Penicillium and 12 allied species. The majority of the analyzed species have been resolved based on cox 1 sequence data and the amplification of cox 1 proved to be more efficient than the other nuclear genes.

Disappointing results on the use of $\operatorname{cox} 1$ for identification of plant pathogenic Fusaria have been provided by Gilmore et al. (2009) [207]. The major limitations which excluded cox1 as a barcode for tagging Fusarium species were: (i) multiple copies (paralogues), (ii) a lack of a species-level resolution within homologous copies, (iii) and the presence of introns affecting amplification efficiency. To date, however, the suitability of other mt-genes for identification of Fusaria has not been tested, due in large part to a lack of available mitogenome sequences.

As mentioned earlier, the presence of mobile introns in fungal mitogenomes appears to be the major source of difficulties in analyzing mitogenome data through PCR and sequencing [186,208]. Santamaria et al. (2009) [208] proved the irregular distribution of mobile introns [209] in almost all the mitochondrial genes of Ascomycota and revealed that only a few nad genes and two rRNA genes do not contain introns, which highlighted their potential applicability for barcoding purposes [208].

Further, an in silico study of Vialle et al. (2009) [210] evaluated the potential of 14 mitochondrial genes for barcoding Basidiomycota species. Mitochondrial genes exhibited high discrimination power, highlighting their promising contribution for the resolution of lower-level relationships, however, the revealed intron presence-absence polymorphism within cox 1 and in six other genes, excluded their potential usefulness for tagging members of Basidiomycota. Three genes: atp6, co3, and nad6 have been shown to exhibit promising characteristics for DNA barcoding of Basidiomycetes, however, no single mt-gene gave a better taxonomic resolution than the ITS region [210].

The most recent study by Liang et al. (2017) [211] evaluated the efficacy of mitogenome sequence in the delimitation of four taxonomically challenging cryptic species within Colletotrichum gloeosporioides sensu lato (C. gloeosporioides, C. fructicola, C. aenigma, and C. siamense s.1.). Reliable delimitation of phylogenetic species in C. gloeosporioides s.l. using prevailing nuclear markers is very challenging due to nascent lineage boundaries. Phylogenetic analysis using mtDNA allowed the generation of a high-resolution phylogeny, recognizing all members of $C$. gloeosporioides s.l. complex. A 142 bp region in the cox3 ORF was identified showing strong lineage-specific divergence. Interestingly, the authors 
suggested that intron presence-absence polymorphism contain a phylogenetic signal, which could be used for designing species-specific approaches. Introns located within $c o b$ and $c o x 1$ genes have been shown to be conserved among all C. gloeosporioides s.l. mitogenomes, however, none of them were found in mitogenomes outside of the $C$. gloeosporioides s.l. complex, highlighting their use for potential diagnostic purposes [211]. A species-specific pattern of intron distribution has been also observed in F. oxysporum [188] and Fusarium fujikuroi species complex (FFSC) [212]. Recently, Gomes et al. (2018) [213] suggested that group I introns are promising targets for developing novel tools for fungicide susceptibility. Some fungicides inhibit self-splicing of group I introns, which is indispensable for pathogen survival under parasitic conditions [213]. Intron distribution has been suggested as an important contributor to the virulence and drug tolerance of human fungal pathogens Cryptococcus neoformans and Cryptococcus gattii. Unfortunately, our knowledge of the role of introns in antifungal tolerance and virulence of plant pathogenic fungi is still lacking.

The barcoding of oomycetes based on cox 1 gene has been first demonstrated by Robideau et al. (2011) [144], through sequence comparison from strains representing 23 genera in this important group of pathogens. It has been proven that in some cases cox1 displayed even higher resolution power than ITS. Robideau et al. (2011) [144] suggested that reliable identification of Pythium and Phytophthora species could be achieved through the combined use of both ITS and cox1. However, the amplification success of cox1 appears to be lineage dependent [214]. To overcome this limitation Choi et al. (2015) [214] proposed incorporation of cox 2 for the barcoding of oomycetes. Primers designed to amplify a portion of cox 2 showed higher amplification success than cox1. Remarkably, cox 2 barcode displayed a barcoding gap with relatively higher scores for identification to the species level from both living samples and from historic herbarium specimens [214].

\section{Conclusions and Future Perspectives}

Recent advances in next-generation sequencing have gained a considerable number of openly available microbial mitogenomes. Massively parallel sequencing platforms can produce millions of short sequences in a single run [215], thereby enabling for sequencing of the whole mitogenomes and proving valuable for searching candidate barcodes for pathogen identification [136]. Universal mitochondrial barcode for both fungi and oomycetes does not exist because the discriminatory power of different barcode regions is not uniformly distributed across the lineages $[136,141,207,214,216]$. For this reason, reliable barcoding of both fungi and oomycetes through mtDNA will require amplification and analysis of multiple barcodes. In the case of fungi, the distribution of some introns and associated HEGs appears to be species-specific, which opens a new window for investigating intronic sequences for diagnostic purposes. This can be only assessed over a significant sample of genera throughout the distributional range.

Despite the unquestionable benefits of NGS (Next Generation Sequencing) applications, sequence length limitations of technologies developed by Illumina, Life Technologies, and Roche justifies the use of short ( $<500 \mathrm{bp}$ ) amplicons for further analyses. Species-level determinations are often impossible for short reads. Enrichment of large fragments of mtDNA especially from environmental samples with long-range PCR could be a viable solution [217,218]. Notably, long-range PCR avoids the risk associated with amplification of NUMTs (nuclear-encoded mitochondrial pseudogenes) and the rearrangements of targeted priming sites with altered gene order [218,219], making sequence assembling less problematic. However, successful amplification with long-range PCR requires high-quality and high-molecular-weight DNA [218], whose recovery from food or environmental samples might pose a considerable challenge. For difficult samples with relatively low-quality DNA, real-time PCR probably remains the best option. Regardless of the selected method, the strong evidence revealed for species-specific polymorphism in fungal mitogenomes opens entirely new directions in fungal diagnostics, which may provide significant benefits in agriculture and food security when the highly sensitive detection of fungi is required. 
Author Contributions: Conceptualization, T.K. and K.B.; resources, T.K.; writing-original draft preparation, T.K.; writing-review and editing, K.B. and M.Ż.; funding acquisition, T.K. All authors have read and agreed to the published version of the manuscript.

Funding: The work was supported by the National Science Center, Poland, grant number 2015/19/B/NZ9/01329. The authors report no declaration of interest.

Conflicts of Interest: The authors declare no conflict of interest. The funders had no role in the design of the study; in the collection, analyses, or interpretation of data; in the writing of the manuscript, or in the decision to publish the results.

\section{References}

1. Fisher, M.C.; Henk, D.A.; Briggs, C.J.; Brownstein, J.S.; Madoff, L.C.; McCraw, S.L.; Gurr, S.J. Emerging fungal threats to animal, plant and ecosystem health. Nature 2012, 484, 186-194. [CrossRef] [PubMed]

2. Fisher, M.C.; Gow, N.A.R.; Gurr, S.J. Tackling emerging fungal threats to animal health, food security and ecosystem resilience. Philos. Trans. R. Soc. B Biol. Sci. 2016, 371, 20160332. [CrossRef] [PubMed]

3. Derevnina, L.; Petre, B.; Kellner, R.; Dagdas, Y.F.; Sarowar, M.N.; Giannakopoulou, A.; de la Concepcion, J.C.; Chaparro-Garcia, A.; Pennington, H.G.; van West, P.; et al. Emerging oomycete threats to plants and animals. Philos. Trans. R. Soc. B Biol. Sci. 2016, 371, 20150459. [CrossRef] [PubMed]

4. Crous, P.W.; Groenewald, J.Z.; Slippers, B.; Wingfield, M.J. Global food and fibre security threatened by current inefficiencies in fungal identification. Philos. Trans. R. Soc. B Biol. Sci. 2016, 371, 20160024. [CrossRef]

5. Latijnhouwers, M.; De Wit, P.J.G.M.; Govers, F. Oomycetes and fungi: Similar weaponry to attack plants. Trends Microbiol. 2003, 11, 462-469. [CrossRef]

6. Richards, T.A.; Dacks, J.B.; Jenkinson, J.M.; Thornton, C.R.; Talbot, N.J. Evolution of filamentous plant pathogens: Gene exchange across eukaryotic kingdoms. Curr. Biol. 2006, 16, 1857-1864. [CrossRef]

7. Persley, D. Diseases of Fruit Crops (No. 634.0493 D611d); Department of Primary Industries: Queensland, Australia, 1993.

8. Ray, M.; Ray, A.; Dash, S.; Mishra, A.; Achary, K.G.; Nayak, S.; Singh, S. Fungal disease detection in plants: Traditional assays, novel diagnostic techniques and biosensors. Biosens. Bioelectron. 2017, 87, 708-723. [CrossRef]

9. Dean, R.; Van Kan, J.A.L.; Pretorius, Z.A.; Hammond-Kosack, K.E.; Di Pietro, A.; Spanu, P.D.; Rudd, J.J.; Dickman, M.; Kahmann, R.; Ellis, J.; et al. The Top 10 fungal pathogens in molecular plant pathology. Mol. Plant. Pathol. 2012, 13, 414-430. [CrossRef]

10. Awika, J.M. Major Cereal grains production and use around the world. In Advances in Cereal Science: Implications to Food Processing and Health Promotion; Awika, J.M., Piironen, V., Bean, S., Eds.; American Chemical Society: Washington, DC, USA, 2011; Volume 1089, pp. 1-13.

11. Romanazzi, G.; Feliziani, E. Botrytis cinerea (Gray Mold). In Postharvest Decay: Control Strategies; Bautista-Baños, S., Ed.; Academic Press: Cambridge, MA, USA, 2014; pp. 131-146.

12. Kang, S.; Demers, J.; Del Mar Jimenez-Gasco, M.; Rep, M. Fusarium oxysporum. In Genomics of Plant-Associated Fungi and Oomycetes: Dicot Pathogens; Dean, R.A., Lichens-Park, A., Kole, C., Eds.; Springer: New York, NY, USA, 2014; pp. 99-119.

13. Diao, Y.Z.; Zhang, C.; Liu, F.; Wang, W.Z.; Liu, L.; Cai, L.; Liu, X.L. Colletotrichum species causing anthracnose disease of chili in China. Persoonia Mol. Phylogeny Evol. Fungi 2017, 38, 20-37. [CrossRef]

14. Marin, S.; Ramos, A.J.; Cano-Sancho, G.; Sanchis, V. Mycotoxins: Occurrence, toxicology, and exposure assessment. Food Chem. Toxicol. 2013, 60, 218-237. [CrossRef]

15. Mu, U.; Cg, O.; Muritala, A. An overview of mycotoxin contamination of foods and feeds. J. Biochem. Microb. 2017, 1, 101.

16. Adeyeye, S.A.O. Fungal mycotoxins in foods: A review. Cogent Food Agric. 2016, 2, 1213127. [CrossRef]

17. Zain, M.E. Impact of mycotoxins on humans and animals. J. Saudi Chem. Soc. 2011, 15, 129-144. [CrossRef]

18. Erwin, D.; Ribeiro, O. Phytophthora Diseases Worldwide; American Phytopathology Society Press: St. Paul, MN, USA, 1996.

19. Haas, B.J.; Kamoun, S.; Zody, M.C.; Jiang, R.H.Y.; Handsaker, R.E.; Cano, L.M.; Grabherr, M.; Kodira, C.D.; Raffaele, S.; Torto-Alalibo, T.; et al. Genome sequence and analysis of the Irish potato famine pathogen Phytophthora infestans. Nature 2009, 461, 393-398. [CrossRef] 
20. Kamoun, S.; Furzer, O.; Jones, J.D.G.; Judelson, H.S.; Ali, G.S.; Dalio, R.J.D.; Roy, S.G.; Schena, L.; Zambounis, A.; Panabières, F.; et al. The Top 10 oomycete pathogens in molecular plant pathology. Mol. Plant. Pathol. 2015, 16, 413-434. [CrossRef] [PubMed]

21. Rizzo, D.M.; Garbelotto, M.; Hansen, E.M. Phytophthora ramorum: Integrative research and management of an emerging pathogen in California and Oregon forests. Annu. Rev. Phytopathol. 2005, 43, 309-335. [CrossRef]

22. Agrios, G. Plant Pathology, 5th ed.; Academic Press: Cambridge, MA, USA, 2004.

23. Lévesque, C.A.; Brouwer, H.; Cano, L.; Hamilton, J.P.; Holt, C.; Huitema, E.; Raffaele, S.; Robideau, G.P.; Thines, M.; Win, J.; et al. Genome sequence of the necrotrophic plant pathogen Pythium ultimum reveals original pathogenicity mechanisms and effector repertoire. Genome Biol. 2010, 11, R73. [CrossRef]

24. Brown, J.K.M.; Hovmøll, M.S. Aerial dispersal of pathogens on the global and continental scales and its impact on plant disease. Science 2002, 297, 537-541. [CrossRef]

25. West, J.S. Plant Pathogen Dispersal. In eLS; John Wiley \& Sons Ltd.: Hoboken, NJ, USA, 2014.

26. Money, N.P. Spore Production, Discharge, and Dispersal. In The Fungi: Third Edition; Watkinson, S.C., Boddy, L., Money, N.P., Eds.; Academic Press: Cambridge, MA, USA, 2016; pp. 67-97.

27. Windle, P.N. Exotic pests: Past, present, and future. In Biological Pollution, an Emerging Global Menace; Britton, K., Ed.; APS Press: St. Paul, MN, USA, 2004; pp. 17-27.

28. Stack, J.P.; Suffert, F.; Gullino, M.L. Bioterrorism: A threat to plant biosecurity? In The Role of Plant. Pathology in Food Safety and Food Security; Strange, R.N., Gullino, M.L., Eds.; Springer: Berlin, Germany, 2010; pp. 115-132.

29. Osman, Z.A.; Elsanousi, S.M.; Elsheikh, E.A.E. Plant materials as probable growth promoters for certain fungi. Asian J. Plant. Sci. Res. 2013, 3, 87-93.

30. Palm, M.E. Systematics and the impact of invasive fungi on agriculture in the United States. Bioscience 2001, 51, 141-147. [CrossRef]

31. Elmer, W.H. Seeds as vehicles for pathogen importation. Biol. Invasions 2001, 3, 262-271. [CrossRef]

32. Alonso Chavez, V.; Parnell, S.; Van den Bosch, F. Monitoring invasive pathogens in plant nurseries for early-detection and to minimise the probability of escape. J. Theor. Biol. 2016, 407, 290-302. [CrossRef]

33. Brasier, C.M. The biosecurity threat to the UK and global environment from international trade in plants. Plant. Pathol. 2008, 57, 792-808. [CrossRef]

34. Parnell, S.; van den Bosch, F.; Gottwald, T.; Gilligan, C.A. Surveillance to inform control of emerging plant diseases: An epidemiological perspective. Annu. Rev. Phytopathol. 2017, 55, 591-610. [CrossRef] [PubMed]

35. Cai, L.; Giraud, T.; Zhang, N.; Begerow, D.; Cai, G.; Shivas, R.G. The evolution of species concepts and species recognition criteria in plant pathogenic fungi. Fungal Divers. 2011, 50, 121. [CrossRef]

36. Cai, L.; Udayanga, D.; Manamgoda, D.S.; Maharachchikumbura, S.S.N.; McKenzie, E.H.C.; Guo, L.D.; Liu, X.Z.; Bahkali, A.; Hyde, K.D. The need to carry out re-inventory of plant pathogenic fungi. Trop. Plant. Pathol. 2011, 36, 205-213. [CrossRef]

37. Raja, H.A.; Miller, A.N.; Pearce, C.J.; Oberlies, N.H. Fungal identification using molecular tools: A primer for the natural products research community. J. Nat. Prod. 2017, 80, 756-770. [CrossRef] [PubMed]

38. Raja, H.A.; Baker, T.R.; Little, J.G.; Oberlies, N.H. DNA barcoding for identification of consumer-relevant mushrooms: A partial solution for product certification? Food Chem. 2017, 214, 383-392. [CrossRef]

39. Capote, N.; Mara, A.; Aguado, A.; Snchez-Torres, P. Molecular tools for detection of plant pathogenic fungi and fungicide resistance. In Plant Pathology; Cumagun, C.J., Ed.; InTech: East Providence, RI, USA, 2012; pp. 151-202.

40. Sharma, P.; Sharma, S. Paradigm shift in plant disease diagnostics: A journey from conventional diagnostics to nano-diagnostics. In Current Trends in Plant Disease Diagnostics and Management Practices; Kumar, P., Gupta, V., Tiwari, A., Kamle, M., Eds.; Springer: Cham, Switzerland, 2016; pp. 237-264.

41. Mancini, V.; Murolo, S.; Romanazzi, G. Diagnostic methods for detecting fungal pathogens on vegetable seeds. Plant. Pathol. 2016, 65, 691-703. [CrossRef]

42. Espindola, A.; Schneider, W.; Hoyt, P.R.; Marek, S.M.; Garzon, C. A new approach for detecting fungal and oomycete plant pathogens in next generation sequencing metagenome data utilising electronic probes. Int. J. Data Min. Bioinform. 2015, 12, 115-128. [CrossRef]

43. Midorikawa, G.E.O.; Miller, R.N.G.; Bittencourt, D.M. de C. Molecular identification and detection of foodborne and feedborne mycotoxigenic fungi. In Molecular Techniques in Food Biology; El Sheikha, A.F., Levin, R., Xu, J., Eds.; John Wiley \& Sons Ltd.: Hoboken, NJ, USA, 2018. 
44. Henson, J.M.; French, R. The polymerase chain reaction and plant disease diagnosis. Annu. Rev. Phytopathol. 1993, 31, 81-109. [CrossRef] [PubMed]

45. Hadidi, A.; Levy, L.; Podleckis, E.V. Polymerase chain reaction technology in plant pathology. In Molecular Methods in Plant Pathology; Singh, R.P., Singh, U.S., Eds.; CRC Press: Boca Raton, FL, USA, 1995.

46. Fang, Y.; Ramasamy, R.P. Current and prospective methods for plant disease detection. Biosensors 2015, 5, 537-561. [CrossRef]

47. Ward, L.; Immanuel, T.M.; Khan, S.; Liefting, L.W.; Delmiglio, C. Conventional PCR. In Molecular Methods in Plant Disease Diagnostics; Boonham, N., Tomlinson, J., Mumford, R., Eds.; CABI: Wallingford, Oxfordshire, UK; Boston, MA, USA, 2016.

48. Van Elsas, J.D; Wolters, A. Polymerase chain reaction (PCR) analysis of soil microbial DNA. In Molecular Microbial Ecology Manual; Akkermans, A.D.L., Van Elsas, J.D., De Bruijn, F.J., Eds.; Springer: Dordrecht, Germany, 1995; pp. 235-244.

49. Yeates, C.; Gillings, M.R.; Davison, A.D.; Altavilla, N.; Veal, D.A. Methods for microbial DNA extraction from soil for PCR amplification. Biol. Proced. Online 1998, 1, 40-47. [CrossRef] [PubMed]

50. Toze, S. PCR and the detection of microbial pathogens in water and wastewater. Water Res. 1999, 33, 3545-3556. [CrossRef]

51. Lorenz, T.C. Polymerase chain reaction: Basic protocol plus troubleshooting and optimization strategies. J. Vis. Exp. 2012, 63, e3998. [CrossRef] [PubMed]

52. Ajmal Ali, M.; Gyulai, G.; Hidvégi, N.; Kerti, B.; Al Hemaid, F.M.A.; Pandey, A.K.; Lee, J. The changing epitome of species identification - DNA barcoding. Saudi, J. Biol. Sci. 2014, 21, 204-231. [CrossRef] [PubMed]

53. Kulik, T.; Ostrowska, A.; Buśko, M.; Pasquali, M.; Beyer, M.; Stenglein, S.; Załuski, D.; Sawicki, J.; Treder, K.; Perkowski, J. Development of an FgMito assay: A highly sensitive mitochondrial based qPCR assay for quantification of Fusarium graminearum sensu stricto. Int. J. Food Microbiol. 2015, 210, 16-23. [CrossRef]

54. Mesquita, A.G.G.; Paula, T.J.; Moreira, M.A.; De Barros, E.G. Identification of races of Colletotrichum lindemuthianum with the aid of PCR-based molecular markers. Plant. Dis. 1998, 82, 1084-1087. [CrossRef]

55. Jiménez-Gasco, M.D.M.; Jiménez-Díaz, R.M. Development of a specific polymerase chain reaction-based assay for the identification of Fusarium oxysporum $\mathrm{f}$. sp. ciceris and its pathogenic races $0,1 \mathrm{~A}, 5$, and 6 . Phytopathology 2003, 93, 200-209. [CrossRef]

56. Lievens, B.; Rep, M.; Thomma, B.P. Recent developments in the molecular discrimination of formae speciales of fusarium oxysporum. Pest. Manag. Sci. 2008, 64, 781-788. [CrossRef]

57. Van Dam, P.; de Sain, M.; ter Horst, A.; van der Gragt, M.; Rep, M. Use of comparative genomics-based markers for discrimination of host specificity in Fusarium oxysporum. Appl. Environ. Microbiol. 2018, 84, e01868-e01917. [CrossRef] [PubMed]

58. Kim, H.; Hwang, S.M.; Lee, J.H.; Oh, M.; Han, J.W.; Choi, G.J. Specific PCR detection of Fusarium oxysporum f. sp. raphani: A causal agent of Fusarium wilt on radish plants. Lett. Appl. Microbiol. 2017, 65, 133-140. [CrossRef] [PubMed]

59. Tang, L.; Gao, Z.G.; Yao, Y.; Liu, X. Identification and genetic diversity of formae speciales of Setosphaeria turcica in China. Plant. Dis. 2015, 99, 482-487. [CrossRef] [PubMed]

60. Kulik, T. Development of TaqMan assays for 3ADON, 15ADON and NIV Fusarium genotypes based on Tri12 gene. Cereal Res. Commun. 2011, 39, 200-214. [CrossRef]

61. Nashima, K.; Terakami, S.; Nishio, S.; Kunihisa, M.; Nishitani, C.; Saito, T.; Yamamoto, T. S-genotype identification based on allele-specific PCR in Japanese pear. Breed. Sci. 2015, 65, 208-215. [CrossRef]

62. Tamura, M.; Ushijima, K.; Sassa, H.; Hirano, H.; Tao, R.; Gradziel, T.M.; Dandekar, A.M. Identification of self-incompatibility genotypes of almond by allele-specific PCR analysis. Theor. Appl. Genet. 2000, 101, 344-349. [CrossRef]

63. Singh, B.P.; Gupta, V.K. Molecular Markers in Mycology. Diagnostics and Marker Developments; Springer International Publishing: Cham, Switzerland, 2017.

64. Upcroft, P.; Upcroft, J.A. Comparison of properties of agarose for electrophoresis of DNA. J. Chromatogr. B Biomed. Sci. Appl. 1993, 618, 79-93. [CrossRef]

65. Aslanzadeh, J. Brief review: Preventing PCR amplification carryover contamination in a clinical laboratory. Ann. Clin. Lab. Sci. 2004, 34, 389-396. 
66. Mirmajlessi, S.M.; Destefanis, M.; Gottsberger, R.A.; Mänd, M.; Loit, E. PCR-based specific techniques used for detecting the most important pathogens on strawberry: A systematic review. Syst. Rev. 2015, 4, 9. [CrossRef]

67. Roberts, P.D.; Jones, J.B.; Chandler, C.K.; Stall, R.E.; Berger, R.D. Survival of Xanthomonas fragariae on strawberry in summer nurseries in Florida detected by specific primers and nested polymerase chain reaction. Plant. Dis. 1996, 8, 1283-1288. [CrossRef]

68. Notomi, T. Loop-medicated isothermal amplification of DNA. Nucleic Acids Res. 2000, 28, E63. [CrossRef] [PubMed]

69. Bergmans, H.E.N.; Gaastra, W. Dot-Blot hybridization method. In New Nucleic Acid Techniques; Walker, J.M., Ed.; Humana Press: Totowa, NJ, USA, 1988; pp. 385-390.

70. Rahman, M.T.; Uddin, M.S.; Sultana, R.; Moue, A.; Setu, M. Polymerase Chain Reaction (PCR): A short review. Anwer Khan Mod. Med. Coll. J. 2013, 4, 30-36. [CrossRef]

71. Clark, D.P.; Pazdernik, N.J. Polymerase Chain Reaction. In Molecular Biology; Elsevier: Amsterdam, The Netherlands, 2013; pp. e55-e61.

72. Alemu, K. Real-Time PCR and its application in plant disease diagnostics. Adv. Life Sci. Technol. 2014, 27, 39-49.

73. Valasek, M.A.; Repa, J.J. The power of real-time PCR. Am. J. Physiol.—Adv. Physiol. Educ. 2005, 29, 151-159. [CrossRef]

74. Jia, Y. Chapter 3-Real-Time PCR. In Methods in Cell Biology; Conn, M.P., Ed.; Academic Press: Cambridge, MA, USA, 2012; Volume 112, pp. 55-68.

75. Heid, C.A.; Stevens, J.; Livak, K.J.; Williams, P.M. Real time quantitative PCR. Genome Res. 1996, 6, $986-994$. [CrossRef] [PubMed]

76. Lees, A.K.; Cullen, D.W.; Sullivan, L.; Nicolson, M.J. Development of conventional and quantitative real-time PCR assays for the detection and identification of Rhizoctonia solani AG-3 in potato and soil. Plant. Pathol. 2002, 51, 293-302. [CrossRef]

77. Shuey, M.M.; Drees, K.P.; Lindner, D.L.; Keim, P.; Foster, J.T. Highly sensitive quantitative PCR for the detection and differentiation of Pseudogymnoascus destructans and other Pseudogymnoascus species. Appl. Environ. Microbiol. 2014, 80, 1726-1731. [CrossRef]

78. Sun, G.; Liu, J.; Li, G.; Zhang, X.; Chen, T.; Chen, J.; Zhang, H.; Wang, D.; Sun, F.; Pan, H. Quick and accurate detection and quantification of magnaporthe oryzae in rice using real-time quantitative polymerase chain reaction. Plant. Dis. 2015, 99, 219-224. [CrossRef]

79. Suarez, M.B.; Walsh, K.; Boonham, N.; O’Neill, T.; Pearson, S.; Barker, I. Development of real-time PCR $\left(\right.$ TaqMan ${ }^{\circledR}$ ) assays for the detection and quantification of Botrytis cinerea in planta. Plant. Physiol. Biochem. 2005, 43, 890-899. [CrossRef]

80. Diguta, C.F.; Rousseaux, S.; Weidmann, S.; Bretin, N.; Vincent, B.; Guilloux-Benatier, M.; Alexandre, H. Development of a qPCR assay for specific quantification of Botrytis cinerea on grapes. FEMS Microbiol. Lett. 2010, 313, 81-87. [CrossRef]

81. Moretti, C.; Quaglia, M.; Cerri, M.; Nicosia, D.E.; Buonaurio, R. A real-time PCR assay for detection and quantification of Botrytis cinerea in Pelargonium $x$ hortorum plants, and its use for evaluation of plant resistance. Eur. J. Plant. Pathol. 2015, 143, 159-171. [CrossRef]

82. Gachon, C.; Saindrenan, P. Real-time PCR monitoring of fungal development in Arabidopsis thaliana infected by Alternaria brassicicola and Botrytis cinerea. Plant. Physiol. Biochem. 2004, 42, 367-371. [CrossRef]

83. Bilska, K.; Kulik, T.; Ostrowska-Kołodziejczak, A.; Buśko, M.; Pasquali, M.; Beyer, M.; Baturo-Cieśniewska, A.; Juda, M.; Załuski, D.; Treder, K.; et al. Development of a highly sensitive FcMito qPCR assay for the quantification of the toxigenic fungal plant pathogen Fusarium culmorum. Toxins 2018, 10, E211. [CrossRef] [PubMed]

84. Nicolaisen, M.; Suproniene, S.; Nielsen, L.K.; Lazzaro, I.; Spliid, N.H.; Justesen, A.F. Real-time PCR for quantification of eleven individual Fusarium species in cereals. J. Microbiol. Methods 2009, 76, 234-240. [CrossRef] [PubMed]

85. Waalwijk, C.; Van Der Heide, R.; De Vries, I.; Van Der Lee, T.; Schoen, C.; Costrel-de Corainville, G.; Häuser-Hahn, I.; Kastelein, P.; Köhl, J.; Lonnet, P.; et al. Quantitative detection of Fusarium species in wheat using TaqMan. Eur. J. Plant. Pathol. 2004, 110, 481-494. [CrossRef] 
86. Haegi, A.; Catalano, V.; Luongo, L.; Vitale, S.; Scotton, M.; Ficcadenti, N.; Belisario, A. A newly developed real-time PCR assay for detection and quantification of Fusarium oxysporum and its use in compatible and incompatible interactions with grafted melon genotypes. Phytopathology 2013, 103, 802-810. [CrossRef]

87. Guo, J.R.; Schnieder, F.; Verreet, J.A. Presymptomatic and quantitative detection of Mycosphaerella graminicola development in wheat using a real-time PCR assay. FEMS Microbiol. Lett. 2006, 262, 223-229. [CrossRef]

88. Abd-Elsalam, K.; Bahkali, A.H.; Moslem, M.; de Wit, P.J.G.M.; Verreet, J.A. Detection of Mycosphaerella graminicola in wheat leaves by a microsatellite dinucleotide specific-primer. Int. J. Mol. Sci. 2011, 12, 682-693. [CrossRef]

89. Debode, J.; Van Hemelrijck, W.; Baeyen, S.; Creemers, P.; Heungens, K.; Maes, M. Quantitative detection and monitoring of colletotrichum acutatum in strawberry leaves using real-time PCR. Plant. Pathol. 2009, 58, 504-514. [CrossRef]

90. Samuelian, S.K.; Greer, L.A.; Savocchia, S.; Steel, C.C. Detection and monitoring of greeneria uvicola and colletotrichum acutatum development on grapevines by real-time PCR. Plant. Dis. 2011, 95, 298-303. [CrossRef]

91. Lees, A.K.; Sullivan, L.; Lynott, J.S.; Cullen, D.W. Development of a quantitative real-time PCR assay for Phytophthora infestans and its applicability to leaf, tuber and soil samples. Plant. Pathol. 2012, 61, 867-876. [CrossRef]

92. Hussain, T.; Singh, B.P.; Anwar, F. A quantitative real time PCR based method for the detection of Phytophthora infestans causing late blight of potato, in infested soil. Saudi, J. Biol. Sci. 2014, 21, 380-386. [CrossRef] [PubMed]

93. Anderson, R.G.; McDowell, J.M. A PCR assay for the quantification of growth of the oomycete pathogen Hyaloperonospora arabidopsidis in Arabidopsis thaliana. Mol. Plant. Pathol. 2015, 16, 893-898. [CrossRef] [PubMed]

94. Hayden, K.J.; Rizzo, D.; Tse, J.; Garbelotto, M. Detection and quantification of Phytophthora ramorum from California forests using a real-time polymerase chain reaction assay. Phytopathology 2004, 94, 1075-1083. [CrossRef] [PubMed]

95. Tooley, P.W.; Martin, F.N.; Carras, M.M.; Frederick, R.D. Real-time fluorescent polymerase chain reaction detection of Phytophthora ramorum and Phytophthora pseudosyringae using mitochondrial gene regions. Phytopathology 2006, 96, 336-345. [CrossRef] [PubMed]

96. Schena, L.; Hughes, K.J.D.; Cooke, D.E.L. Detection and quantification of Phytophthora ramorum, P. kernoviae, P. citricola and P. quercina in symptomatic leaves by multiplex real-time PCR. Mol. Plant. Pathol. 2006, 7, 365-379. [CrossRef]

97. Bienapfl, J.C.; Malvick, D.K.; Percich, J.A. Specific molecular detection of Phytophthora sojae using conventional and real-time PCR. Fungal Biol. 2011, 115, 733-740. [CrossRef]

98. Catal, M.; Erler, F.; Fulbright, D.W.; Adams, G.C. Real-time quantitative PCR assays for evaluation of soybean varieties for resistance to the stem and root rot pathogen Phytophthora sojae. Eur. J. Plant. Pathol. 2013, 137, 859-869. [CrossRef]

99. Silvar, C.; Díaz, J.; Merino, F. Real-time polymerase chain reaction quantification of Phytophthora capsici in different pepper genotypes. Phytopathology 2005, 95, 1423-1429. [CrossRef]

100. Valsesia, G.; Gobbin, D.; Patocchi, A.; Vecchione, A.; Pertot, I.; Gessler, C. Development of a high-throughput method for quantification of Plasmopara viticola DNA in grapevine leaves by means of quantitative real-time polymerase chain reaction. Phytopathology 2005, 95, 672-678. [CrossRef]

101. Engelbrecht, J.; Duong, T.A.; van den Berg, N. Development of a nested quantitative real-time PCR for detecting Phytophthora cinnamomi in Persea americana rootstocks. Plant. Dis. 2013, 97, 1012-1017. [CrossRef]

102. Schroeder, K.L.; Okubara, P.A.; Tambong, J.T.; Lévesque, C.A.; Paulitz, T.C. Identification and quantification of pathogenic Pythium spp. from soils in eastern Washington using real-time polymerase chain reaction. Phytopathology 2006, 96, 637-647. [CrossRef]

103. Lievens, B.; Brouwer, M.; Vanachter, A.C.R.C.; Cammue, B.P.A.; Thomma, B.P.H.J. Real-time PCR for detection and quantification of fungal and oomycete tomato pathogens in plant and soil samples. Plant. Sci. 2006, 171, 155-165. [CrossRef] 
104. Spies, C.F.J.; Mazzola, M.; McLeod, A. Characterisation and detection of Pythium and Phytophthora species associated with grapevines in South Africa. Eur. J. Plant. Pathol. 2011, 131, 103. [CrossRef]

105. Demeke, T.; Gräfenhan, T.; Clear, R.M.; Phan, A.; Ratnayaka, I.; Chapados, J.; Patrick, S.K.; Gaba, D.; Lévesque, C.A.; Seifert, K.A. Development of a specific TaqMan ${ }^{\circledR}$ real-time PCR assay for quantification of Fusarium graminearum clade 7 and comparison of fungal biomass determined by PCR with deoxynivalenol content in wheat and barley. Int. J. Food Microbiol. 2010, 141, 45-50. [CrossRef]

106. Tao, G.; Hyde, K.D.; Cai, L. Species-specific real-time PCR detection of Colletotrichum kahawae. J. Appl. Microbiol. 2013, 114, 828-835. [CrossRef]

107. Huang, C.H.; Tsai, R.T.; Vallad, G.E. Development of a TaqMan Real-Time Polymerase Chain Reaction assay for detection and quantification of Fusarium oxysporum f. sp. lycopersici in Soil. J. Phytopathol. 2016, 164, 455-463. [CrossRef]

108. Lin, Y.H.; Su, C.C.; Chao, C.P.; Chen, C.Y.; Chang, C.J.; Huang, J.W.; Chang, P.F.L. A molecular diagnosis method using real-time PCR for quantification and detection of Fusarium oxysporum $\mathrm{f}$. sp. cubense race 4. Eur. J. Plant. Pathol. 2013, 135, 395-405. [CrossRef]

109. Aguayo, J.; Mostert, D.; Fourrier-Jeandel, C.; Cerf-Wendling, I.; Hostachy, B.; Viljoen, A.; Ioos, R. Development of a hydrolysis probe-based real-time assay for the detection of tropical strains of Fusarium oxysporum $\mathrm{f}$. Sp. Cubense race 4. PLoS ONE 2017, 12, e0171767. [CrossRef]

110. De Sousa, M.V.; Machado, J.D.C.; Simmons, H.E.; Munkvold, G.P. Real-time quantitative PCR assays for the rapid detection and quantification of Fusarium oxysporum f. sp. phaseoli in Phaseolus vulgaris (common bean) seeds. Plant. Pathol. 2015, 64, 478-488. [CrossRef]

111. Okubara, P.A.; Harrison, L.A.; Gatch, E.W.; Vandemark, G.; Schroeder, K.L.; du Toit, L.J. Development and evaluation of a TaqMan real-time PCR assay for Fusarium oxysporum f. sp. spinaciae. Plant. Dis. 2013. [CrossRef] [PubMed]

112. Sayler, R.J.; Yang, Y. Detection and quantification of Rhizoctonia solani AG-1 IA, the rice sheath blight pathogen, in rice using real-time PCR. Plant. Dis. 2007, 97, 927-937.

113. Tao, G.; Liu, Z.Y.; Liu, F.; Gao, Y.H.; Cai, L. Endophytic Colletotrichum species from Bletilla ochracea (Orchidaceae), with descriptions of seven new speices. Fungal Divers. 2013, 61, 139-164. [CrossRef]

114. O’Donnell, K.; Ward, T.J.; Geiser, D.M.; Kistler, H.C.; Aoki, T. Genealogical concordance between the mating type locus and seven other nuclear genes supports formal recognition of nine phylogenetically distinct species within the Fusarium graminearum clade. Fungal Genet. Biol. 2004, 41, 600-623. [CrossRef]

115. Starkey, D.E.; Ward, T.J.; Aoki, T.; Gale, L.R.; Kistler, H.C.; Geiser, D.M.; Suga, H.; Tóth, B.; Varga, J.; O'Donnell, K. Global molecular surveillance reveals novel Fusarium head blight species and trichothecene toxin diversity. Fungal Genet. Biol. 2007, 44, 1191-1204. [CrossRef]

116. Shivas, R.G.; Tan, Y.P. A taxonomic re-assessment of Colletotrichum acutatum, introducing C. fioriniae comb. et stat. nov. and C. simmondsii sp. nov. Fungal Divers. 2009, 39, 111-122.

117. Damm, U.; Woudenberg, J.H.C.; Cannon, P.F.; Crous, P.W. Colletotrichum species with curved conidia from herbaceous hosts. Fungal Divers. 2009, 39, 45-87.

118. Stewart, J.E.; Timmer, L.W.; Lawrence, C.B.; Pryor, B.M.; Peever, T.L. Discord between morphological and phylogenetic species boundaries: Incomplete lineage sorting and recombination results in fuzzy species boundaries in an asexual fungal pathogen. BMC Evol. Biol. 2014, 14, 38. [CrossRef]

119. Feau, N.; Decourcelle, T.; Husson, C.; Desprez-Loustau, M.L.; Dutech, C. Finding single copy genes out of sequenced genomes for multilocus phylogenetics in non-model fungi. PLoS ONE 2011, 6, e18803. [CrossRef]

120. Pöggeler, S.; Nowrousian, M.; Ringelberg, C.; Loros, J.J.; Dunlap, J.C.; Kück, U. Microarray and real-time PCR analyses reveal mating type-dependent gene expression in a homothallic fungus. Mol. Genet. Genomics 2006, 275, 492-503. [CrossRef]

121. Czaja, W.; Miller, K.Y.; Miller, B.L. Complex mechanisms regulate developmental expression of the matA (HMG) mating type gene in homothallic Aspergillus nidulans. Genetics 2011, 189, 795-808. [CrossRef] [PubMed]

122. Gagnon, M.C.; Kawchuk, L.; Mathieu Tremblay, D.; Carisse, O.; Danies, G.; Fry, W.E.; Lévesque, C.A.; Bilodeau, G.J. Identification of the dominant genotypes of phytophthora infestans in Canada using real-time PCR with ASO-PCR Assays. Plant. Dis. 2016, 100, 1482-1491. [CrossRef] [PubMed]

123. Luchi, N.; Ioos, R.; Santini, A. Fast and reliable molecular methods to detect fungal pathogens in woody plants. Appl. Microbiol. Biotechnol. 2020, 104, 2453-2468. [CrossRef] [PubMed] 
124. Klimek-Ochab, M.; Brzezińska-Rodak, M.; Zymańczyk-Duda, E.; Lejczak, B.; Kafarski, P. Comparative study of fungal cell disruption-scope and limitations of the methods. Folia Microbiol. (Praha). 2011, 56, 469-475. [CrossRef] [PubMed]

125. Schumann, U.; Smith, N.A.; Wang, M.B. A fast and efficient method for preparation of high-quality RNA from fungal mycelia. BMC Res. Notes 2013, 6, 71. [CrossRef] [PubMed]

126. Taniwaki, M.H.; Pitt, J.I.; Hocking, A.D.; Fleet, G.H. Comparison of hyphal length, ergosterol, mycelium dry weight, and colony diameter for quantifying growth of fungi from foods. In Proceedings of the Advances in Experimental Medicine and Biology; Hocking, A.D., Pitt, J.I., Samson, R.A., Thrane, U., Eds.; Springer: Berlin, Germany, 2005; pp. 49-67.

127. Grosdidier, M.; Aguayo, J.; Marçais, B.; Ioos, R. Detection of plant pathogens using real-time PCR: How reliable are late Ct values? Plant. Pathol. 2017, 66, 359-367. [CrossRef]

128. Martin, F.N.; Tooley, P.W.; Blomquist, C. Molecular detection of Phytophthora ramorum, the causal agent of sudden oak death in California, and two additional species commonly recovered from diseased plant material. Phytopathology 2004, 94, 621-631. [CrossRef]

129. Yin, J.L.; Shackel, N.A.; Zekry, A.; McGuinness, P.H.; Richards, C.; Van Der Putten, K.; McCaughan, G.W.; Eris, J.M.; Bishop, G.A. Real-time reverse transcriptase-polymerase chain reaction (RT-PCR) for measurement of cytokine and growth factor mRNA expression with fluorogenic probes or SYBR Green I. Immunol. Cell Biol. 2001, 79, 213-221. [CrossRef]

130. Feckler, A.; Schrimpf, A.; Bundschuh, M.; Bärlocher, F.; Baudy, P.; Cornut, J.; Schulz, R. Quantitative real-time PCR as a promising tool for the detection and quantification of leafassociated fungal species - A proof-ofconcept using Alatospora pulchella. PLoS ONE 2017, 12, e0174634. [CrossRef]

131. Veronesi, F.; Santoro, A.; Milardi, G.L.; Diaferia, M.; Branciari, R.; Miraglia, D.; Cioffi, A.; Gabrielli, S.; Ranucci, D. Comparison of PCR assays targeting the multi-copy targets B1 gene and 529 bp repetitive element for detection of Toxoplasma gondii in swine muscle. Food Microbiol. 2017, 63, 213-216. [CrossRef]

132. Fenollar, F.; Fournier, P.E.; Robert, C.; Raoult, D. Use of genome selected repeated sequences increases the sensitivity of PCR detection of Tropheryma whipplei. J. Clin. Microbiol. 2004, 42, 401-403. [CrossRef] [PubMed]

133. Kress, W.J.; Erickson, D.L. DNA Barcodes: Methods and Protocols. In DNA Barcodes; Kress, W.J., Erickson, D.L., Eds.; Humana Press: Totowa, NJ, USA, 2012; pp. 3-8.

134. Hollingsworth, P.M.; Graham, S.W.; Little, D.P. Choosing and using a plant DNA barcode. PLoS ONE 2011, 6, e19254. [CrossRef] [PubMed]

135. Eberhardt, U. Methods for DNA Barcoding of Fungi. In DNA Barcodes; Kress, W.J., Erickson, D.L., Eds.; Humana Press: Totowa, NJ, USA, 2012; pp. 183-205.

136. Xu, J. Fungal DNA barcoding1. Genome 2016, 59, 913-932. [CrossRef]

137. Riit, T.; Tedersoo, L.; Drenkhan, R.; Runno-Paurson, E.; Kokko, H.; Anslan, S. Oomycete-specific ITS primers for identification and metabarcoding. MycoKeys 2016, 14, 17-30. [CrossRef]

138. Kress, W.J.; García-Robledo, C.; Uriarte, M.; Erickson, D.L. DNA barcodes for ecology, evolution, and conservation. Trends Ecol. Evol. 2015, 30, 25-35. [CrossRef]

139. Gao, R.; Zhang, G. Potential of DNA barcoding for detecting quarantine fungi. Phytopathology 2013, 103, 1103-1107. [CrossRef]

140. Hebert, P.D.N.; Cywinska, A.; Ball, S.L.; DeWaard, J.R. Biological identifications through DNA barcodes. Proc. R. Soc. B Biol. Sci. 2003, 270, 313-321. [CrossRef]

141. Seifert, K.A. Progress towards DNA barcoding of fungi. Mol. Ecol. Resour. 2009, 9, 83-89. [CrossRef]

142. Seifert, K.A.; Samson, R.A.; DeWaard, J.R.; Houbraken, J.; Lévesque, C.A.; Moncalvo, J.M.; Louis-Seize, G.; Hebert, P.D.N. Prospects for fungus identification using CO1 DNA barcodes, with Penicillium as a test case. Proc. Natl. Acad. Sci. USA 2007, 104, 3901-3906. [CrossRef]

143. Schoch, C.L.; Seifert, K.A.; Huhndorf, S.; Robert, V.; Spouge, J.L.; Levesque, C.A.; Chen, W.; Bolchacova, E.; Voigt, K.; Crous, P.W.; et al. Nuclear ribosomal internal transcribed spacer (ITS) region as a universal DNA barcode marker for Fungi. Proc. Natl. Acad. Sci. USA 2012, 109, 6241-6246. [CrossRef]

144. Robideau, G.P.; De Cock, A.W.A.M.; Coffey, M.D.; Voglmayr, H.; Brouwer, H.; Bala, K.; Chitty, D.W.; Désaulniers, N.; Eggertson, Q.A.; Gachon, C.M.M.; et al. DNA barcoding of oomycetes with cytochrome c oxidase subunit I and internal transcribed spacer. Mol. Ecol. Resour. 2011, 11, 1002-1011. [CrossRef] 
145. Kiss, L. Limits of nuclear ribosomal DNA internal transcribed spacer (ITS) sequences as species barcodes for Fungi. Proc. Natl. Acad. Sci. USA 2012, 109, e1811. [CrossRef]

146. Sharma, R.; Polkade, A.V.; Shouche, Y.S. "Species concept" in microbial taxonomy and systematics. Curr. Sci. 2015, 108, 1804-1814.

147. Kashyap, P.L.; Rai, P.; Kumar, S.; Chakdar, H.; Srivastava, A.K. DNA barcoding for diagnosis and monitoring of fungal plant pathogens. In Molecular Markers in Mycology; Singh, B.P., Gupta, V.K., Eds.; Springer: Berlin, Germany, 2017; pp. 87-122.

148. Thines, M. Repeats of the ITS2 of Plasmopara species and their relevance for phylogenetic studies. In Advances in Downy Mildew Research. Vol. 3; Lebeda, A., Spencer-Philips, P., Eds.; Palacký University and JOLA, v.o.s: Olomouc and Kostelec na Hané: Olomouc, Czech Republic, 2007; pp. 31-35.

149. Goodwin, S.B.; Legard, D.E.; Smart, C.D.; Levy, M.; Fry, W.E. Gene flow analysis of molecular markers confirms that Phytophthora mirabilis and P. infestans are separate species. Mycologia 1999, 91, 796. [CrossRef]

150. Cooke, D.E.L.; Drenth, A.; Duncan, J.M.; Wagels, G.; Brasier, C.M. A molecular phylogeny of Phytophthora and related Oomycetes. Fungal Genet. Biol. 2000, 30, 17-32. [CrossRef]

151. Jung, T.; Burgess, T.I. Re-evaluation of Phytophthora citricola isolates from multiple woody hosts in Europe and North America reveals a new species, Phytophthora plurivora sp. nov. Persoonia-Mol. Phylogeny Evol. Fungi 2009, 22, 95-110. [CrossRef]

152. Choi, Y.-J.; Hong, S.-B.; Shin, H.-D. Re-consideration of Peronospora farinosa infecting Spinacia oleracea as distinct species, Peronospora effusa. Mycol. Res. 2007, 111, 381-391. [CrossRef]

153. Voglmayr, H.; Montes-Borrego, M.; Landa, B.B. Disentangling Peronospora on Papaver: Phylogenetics, taxonomy, nomenclature and host range of downy mildew of opium poppy (Papaver somniferum) and related species. PLoS ONE 2014, 9, e96838. [CrossRef]

154. O’Donnell, K.; Rooney, A.P.; Proctor, R.H.; Brown, D.W.; McCormick, S.P.; Ward, T.J.; Frandsen, R.J.N.; Lysøe, E.; Rehner, S.A.; Aoki, T.; et al. Phylogenetic analyses of RPB1 and RPB2 support a middle Cretaceous origin for a clade comprising all agriculturally and medically important fusaria. Fungal Genet. Biol. 2013, 52, 20-31. [CrossRef]

155. Rai, S.; Kashyap, P.L.; Kumar, S.; Srivastava, A.K.; Ramteke, P.W. Identification, characterization and phylogenetic analysis of antifungal Trichoderma from tomato rhizosphere. Springerplus 2016, 5, 1939. [CrossRef]

156. Kristensen, R.; Torp, M.; Kosiak, B.; Holst-Jensen, A. Phylogeny and toxigenic potential is correlated in Fusarium species as revealed by partial translation elongation factor 1 alpha gene sequences. Mycol. Res. 2005, 109, 173-186. [CrossRef]

157. Knutsen, A.K.; Torp, M.; Holst-Jensen, A. Phylogenetic analyses of the Fusarium poae, Fusarium sporotrichioides and Fusarium langsethiae species complex based on partial sequences of the translation elongation factor-1 alpha gene. Int. J. Food Microbiol. 2004, 95, 287-295. [CrossRef]

158. Geiser, D.M.; Jiménez-Gasco, M.D.M.; Kang, S.; Makalowska, I.; Veeraraghavan, N.; Ward, T.J.; Zhang, N.; Kuldau, G.A.; O’Donnell, K. FUSARIUM-ID v. 1.0: A DNA sequence database for identifying Fusarium. Eur. J. Plant. Pathol. 2004, 110, 473-479. [CrossRef]

159. Aroca, A.; Raposo, R.; Lunello, P. A biomarker for the identification of four Phaeoacremonium species using the $\beta$-tubulin gene as the target sequence. Appl. Microbiol. Biotechnol. 2008, 80, 1131-1140. [CrossRef]

160. Mostert, L.; Groenewald, J.Z.; Summerbell, R.C.; Gams, W.; Crous, P.W. Taxonomy and pathology of Togninia (Diaporthales) and its Phaeoacremonium anamorphs. Stud. Mycol. 2006, 54, 1-113. [CrossRef]

161. Fraaije, B.A.; Lovell, D.J.; Coelho, J.M.; Baldwin, S.; Hollomon, D.W. PCR-based assays to assess wheat varietal resistance to blotch (Septoria tritici and Stagonospora nodorum) and rust (Puccinia striiformis and Puccinia recondita) diseases. Eur. J. Plant. Pathol. 2001, 107, 905-917. [CrossRef]

162. De Beer, Z.W.; Duong, T.A.; Barnes, I.; Wingfield, B.D.; Wingfield, M.J. Redefining Ceratocystis and allied genera. Stud. Mycol. 2014, 79, 187-219. [CrossRef]

163. Mulè, G.; Susca, A.; Stea, G.; Moretti, A. Specific detection of the toxigenic species Fusarium proliferatum and F. oxysporum from asparagus plants using primers based on calmodulin gene sequences. FEMS Microbiol. Lett. 2004, 230, 235-240. [CrossRef]

164. Hatsch, D.; Phalip, V.; Jeltsch, J.M. Use of genes encoding cellobiohydrolase-C and topoisomerase II as targets for phylogenetic analysis and identification of Fusarium. Res. Microbiol. 2004, 155, 290-296. [CrossRef] 
165. Stielow, J.B.; Lévesque, C.A.; Seifert, K.A.; Meyer, W.; Irinyi, L.; Smits, D.; Renfurm, R.; Verkley, G.J.M.; Groenewald, M.; Chaduli, D.; et al. One fungus, which genes? Development and assessment of universal primers for potential secondary fungal DNA barcodes. Persoonia Mol. Phylogeny Evol. Fungi 2015, 35, 242-263. [CrossRef]

166. Nguyen, H.D.T.; Jančič, S.; Meijer, M.; Tanney, J.B.; Zalar, P.; Gunde-Cimerman, N.; Seifert, K.A. Application of the phylogenetic species concept to wallemia sebi from house dust and indoor air revealed by multi-locus genealogical concordance. PLoS ONE 2015, 10, e0120894. [CrossRef]

167. Balasundaram, S.V.; Engh, I.B.; Skrede, I.; Kauserud, H. How many DNA markers are needed to reveal cryptic fungal species? Fungal Biol. 2015, 119, 940-945. [CrossRef]

168. Laurence, M.H.; Summerell, B.A.; Burgess, L.W.; Liew, E.C.Y. Genealogical concordance phylogenetic species recognition in the Fusarium oxysporum species complex. Fungal Biol. 2014, 118, 374-384. [CrossRef]

169. Bartelli, T.F.; Bruno, D.C.F.; Briones, M.R.S. Evidence for mitochondrial genome methylation in the yeast Candida albicans: A potential novel epigenetic mechanism affecting adaptation and pathogenicity? Front. Genet. 2018, 9, 166. [CrossRef]

170. Chatre, L.; Ricchetti, M. Are mitochondria the Achilles' heel of the Kingdom Fungi? Curr. Opin. Microbiol. 2014, 20, 49-54. [CrossRef]

171. Calderone, R.; Li, D.M.; Traven, A. System-level impact of mitochondria on fungal virulence: To metabolism and beyond. FEMS Yeast Res. 2015, 15. [CrossRef]

172. Sandor, S.; Zhang, Y.J.; Xu, J.P. Fungal mitochondrial genomes and genetic polymorphisms. Appl. Microbiol. Biotechnol. 2018, 102, 9433-9448. [CrossRef]

173. Shingu-Vazquez, M.; Traven, A. Mitochondria and fungal pathogenesis: Drug tolerance, virulence, and potential for antifungal therapy. Eukaryot. Cell 2011, 10, 1376-1383. [CrossRef]

174. Hausner, G. Fungal mitochondrial genomes, plasmids and introns. In Applied Mycology and Biotechnology; Arora, D.K., Khachatourians, G.G., Eds.; Elsevier: Amsterdam, The Netherlands, 2003; Volume 3, pp. 101-131.

175. Aguileta, G.; de Vienne, D.M.; Ross, O.N.; Hood, M.E.; Giraud, T.; Petit, E.; Gabaldon, T. High variability of mitochondrial gene order among fungi. Genome Biol. Evol. 2014, 6, 451-465. [CrossRef]

176. Franco, M.E.E.; Lopez, S.M.Y.; Medina, R.; Lucentini, C.G.; Troncozo, M.I.; Pastorino, G.N.; Saparrat, M.C.N.; Balatti, P.A. The mitochondrial genome of the plant-pathogenic fungus Stemphylium lycopersici uncovers a dynamic structure due to repetitive and mobile elements. PLOS ONE 2017, 12, e0185545. [CrossRef]

177. Bullerwell, C.E.; Lang, B.F. Fungal evolution: The case of the vanishing mitochondrion. Curr. Opin. Microbiol. 2005, 8, 362-369. [CrossRef]

178. Mardanov, A.V.; Beletsky, A.V.; Kadnikov, V.V.; Ignatov, A.N.; Ravin, N.V. The 203 kbp mitochondrial genome of the phytopathogenic fungus sclerotinia borealis reveals multiple invasions of introns and genomic duplications. PLOS ONE 2014, 9, e107536. [CrossRef]

179. Losada, L.; Pakala, S.B.; Fedorova, N.D.; Joardar, V.; Shabalina, S.A.; Hostetler, J.; Pakala, S.M.; Zafar, N.; Thomas, E.; Rodriguez-Carres, M.; et al. Mobile elements and mitochondrial genome expansion in the soil fungus and potato pathogen Rhizoctonia solani AG-3. Fems Microbiol. Lett. 2014, 352, 165-173. [CrossRef]

180. Basse, C.W. Mitochondrial inheritance in fungi. Curr. Opin. Microbiol. 2010, 13, 712-719. [CrossRef]

181. Wilson, A.J.; Xu, J. Mitochondrial inheritance: Diverse patterns and mechanisms with an emphasis on fungi. Mycology 2012, 3, 158-166.

182. Xu, J.; Li, H. Current perspectives on mitochondrial inheritance in fungi. Cell Health Cytoskelet. 2015, 7, 143. [CrossRef]

183. Xu, J.; Wang, P. Mitochondrial inheritance in basidiomycete fungi. Fungal Biol. Rev. 2015, 29, $209-219$. [CrossRef]

184. Lang, B.F.; Laforest, M.J.; Burger, G. Mitochondrial introns: A critical view. Trends Genet. 2007, 23, 119-125. [CrossRef]

185. Lambowitz, A.M.; Zimmerly, S. Group II introns: Mobile ribozymes that invade DNA. Cold Spring Harb. Perspect. Biol. 2011, 3, a003616. [CrossRef]

186. Joardar, V.; Abrams, N.F.; Hostetler, J.; Paukstelis, P.J.; Pakala, S.; Pakala, S.B.; Zafar, N.; Abolude, O.O.; Payne, G.; Andrianopoulos, A.; et al. Sequencing of mitochondrial genomes of nine Aspergillus and Penicillium species identifies mobile introns and accessory genes as main sources of genome size variability. BMC Genomics 2012, 13, 698. [CrossRef] 
187. Pogoda, C.S.; Keepers, K.G.; Nadiadi, A.Y.; Bailey, D.W.; Lendemer, J.C.; Tripp, E.A.; Kane, N.C. Genome streamlining via complete loss of introns has occurred multiple times in lichenized fungal mitochondria. Ecol. Evol. 2019, 9, 4245-4263. [CrossRef]

188. Brankovics, B.; van Dam, P.; Rep, M.; de Hoog, G.S.; van der Lee, T.A.J.; Waalwijk, C.; van Diepeningen, A.D. Mitochondrial genomes reveal recombination in the presumed asexual Fusarium oxysporum species complex. BMC Genomics 2017, 18, 735. [CrossRef]

189. Yin, L.F.; Hu, M.J.; Wang, F.; Kuang, H.H.; Zhang, Y.; Schnabel, G.; Li, G.Q.; Luo, C.X. Frequent Gain and Loss of Introns in Fungal Cytochrome b Genes. PLoS ONE 2012, 7, e49096. [CrossRef]

190. Kolesnikova, A.I.; Putintseva, Y.A.; Simonov, E.P.; Biriukov, V.V.; Oreshkova, N.V.; Pavlov, I.N.; Sharov, V.V.; Kuzmin, D.A.; Anderson, J.B.; Krutovsky, K.V. Mobile genetic elements explain size variation in the mitochondrial genomes of four closely-related Armillaria species. BMC Genomics 2019, 20, 351. [CrossRef]

191. Hooks, K.B.; Delneri, D.; Griffiths-Jones, S. Intron evolution in Saccharomycetaceae. Genome Biol. Evol. 2014, 6, 2543-2556. [CrossRef]

192. Yuan, X.; Feng, C.; Zhang, Z.; Zhang, C. Complete mitochondrial genome of Phytophthora nicotianae and identification of molecular markers for the oomycetes. Front. Microbiol. 2017, 8, 1484. [CrossRef]

193. Martin, F.N.; Zhang, Y.; Cooke, D.E.L.; Coffey, M.D.; Grünwald, N.J.; Fry, W.E. Insights into evolving global populations of Phytophthora infestans via new complementary mtDNA haplotype markers and nuclear SSRs. PLoS ONE 2019, 14, e0208606. [CrossRef]

194. Martinelli, F.; Scalenghe, R.; Davino, S.; Panno, S.; Scuderi, G.; Ruisi, P.; Villa, P.; Stroppiana, D.; Boschetti, M.; Goulart, L.R.; et al. Advanced methods of plant disease detection. A review. Agron. Sustain. Dev. 2015, 35, 1-25. [CrossRef]

195. Taanman, J.W. The mitochondrial genome: Structure, transcription, translation and replication. Biochim. Biophys. Acta - Bioenerg. 1999, 1410, 103-123. [CrossRef]

196. Chinnery, P.F.; Hudson, G. Mitochondrial genetics. Br. Med. Bull. 2013, 106, 135-159. [CrossRef]

197. Costa, C.; Vidaud, D.; Olivi, M.; Bart-Delabesse, E.; Vidaud, M.; Bretagne, S. Development of two real-time quantitative TaqMan PCR assays to detect circulating Aspergillus fumigatus DNA in serum. J. Microbiol. Methods 2001, 44, 263-269. [CrossRef]

198. Rantakokko-Jalava, K.; Laaksonen, S.; Issakainen, J.; Vauras, J.; Nikoskelainen, J.; Viljanen, M.K.; Salonen, J. Semiquantitative detection by real-time PCR of Aspergillus fumigatus in bronchoalveolar lavage fluids and tissue biopsy specimens from patients with invasive aspergillosis. J. Clin. Microbiol. 2003, 41, 4304-4311. [CrossRef]

199. Millon, L.; Grenouillet, F.; Legrand, F.; Loewert, S.; Bellanger, A.P.; Gbaguidi-Haore, H.; Scherer, E.; Henon, T.; Rohrlich, P.; Deconinck, E. Ribosomal and mitochondrial DNA target for real-time PCR diagnosis of invasive aspergillosis. J. Clin. Microbiol. 2011, 49, 1058-1063. [CrossRef]

200. Gao, X.; Jackson, T.A.; Lambert, K.N.; Li, S.; Hartman, G.L.; Niblack, T.L. Detection and quantification of Fusarium solani f. sp. glycines in soybean roots with real-time quantitative polymerase chain reaction. Plant. Dis. 2004, 88, 1372-1380. [CrossRef]

201. Li, S.; Hartman, G.L.; Domier, L.L.; Boykin, D. Quantification of Fusarium solani f. sp. glycines isolates in soybean roots by colony-forming unit assays and real-time quantitative PCR. Theor. Appl. Genet. 2008, 117, 343-352. [CrossRef]

202. Mbofung, G.C.Y.; Fessehaie, A.; Bhattacharyya, M.K.; Leandro, L.F.S. A new TaqMan real-time polymerase chain reaction assay for quantification of Fusarium virguliforme in soil. Plant. Dis. 2011, 95, 1420-1426. [CrossRef]

203. Aoki, T.; O'Donnell, K.; Scandiani, M.M. Sudden death syndrome of soybean in South America is caused by four species of Fusarium: Fusarium brasiliense sp. nov., F. cuneirostrum sp. nov., F. tucumaniae, and F. virguliforme. Mycoscience 2005, 46, 162-183. [CrossRef]

204. O’Donnell, K.; Sink, S.; Scandiani, M.M.; Luque, A.; Colletto, A.; Biasoli, M.; Lenzi, L.; Salas, G.; González, V.; Ploper, L.D.; et al. Soybean sudden death syndrome species diversity within North and South America revealed by multilocus genotyping. Phytopathology 2010, 100, 58-71. [CrossRef]

205. Sarver, B.A.J.; Ward, T.J.; Gale, L.R.; Broz, K.; Corby Kistler, H.; Aoki, T.; Nicholson, P.; Carter, J.; O’Donnell, K. Novel Fusarium head blight pathogens from Nepal and Louisiana revealed by multilocus genealogical concordance. Fungal Genet. Biol. 2011, 48, 1096-1107. [CrossRef] 
206. Bilodeau, G.J.; Martin, F.N.; Coffey, M.D.; Blomquist, C.L. Development of a multiplex assay for genus- and species-specific detection of phytophthora based on differences in mitochondrial gene order. Phytopathology 2014, 104, 733-748. [CrossRef]

207. Gilmore, S.R.; GrÄfenhan, T.; Louis-Seize, G.; Seifert, K.A. Multiple copies of cytochrome oxidase 1 in species of the fungal genus Fusarium. Mol. Ecol. Resour. 2009, 9, 90-98. [CrossRef]

208. Santamaria, M.; Vicario, S.; Pappadà, G.; Scioscia, G.; Scazzocchio, C.; Saccone, C. Towards barcode markers in Fungi: An intron map of Ascomycota mitochondria. BMC Bioinformatics 2009, 10, S15. [CrossRef]

209. Hamari, Z.; Juhász, Á.; Kevei, F. Role of mobile introns in mitochondrial genome diversity of fungi: (A mini review). Acta Microbiol. Immunol. Hung. 2002, 49, 331-335. [CrossRef]

210. Vialle, A.; Feau, N.; Allaire, M.; Didukh, M.; Martin, F.; Moncalvo, J.M.; Hamelin, R.C. Evaluation of mitochondrial genes as DNA barcode for Basidiomycota. Mol. Ecol. Resour. 2009, 9, 99-113. [CrossRef]

211. Liang, X.; Tian, X.; Liu, W.; Wei, T.; Wang, W.; Dong, Q.; Wang, B.; Meng, Y.; Zhang, R.; Gleason, M.L.; et al. Comparative analysis of the mitochondrial genomes of Colletotrichum gloeosporioides sensu lato: Insights into the evolution of a fungal species complex interacting with diverse plants. BMC Genomics 2017, 18, 171. [CrossRef]

212. Fourie, G.; Van der Merwe, N.A.; Wingfield, B.D.; Bogale, M.; Wingfield, M.J.; Steenkamp, E.T. Mitochondrial introgression and interspecies recombination in the Fusarium fujikuroi species complex. IMA Fungus 2018, 9 , 37-48. [CrossRef]

213. Gomes, F.E.E.S.; Arantes, T.D.; Fernandes, J.A.L.; Ferreira, L.C.; Romero, H.; Bosco, S.M.G.; Oliveira, M.T.B.; Del Negro, G.M.B.; Theodoro, R.C. Polymorphism in mitochondrial group I introns among Cryptococcus neoformans and Cryptococcus gattii genotypes and its association with drug susceptibility. Front. Microbiol. 2018, 9, 86. [CrossRef]

214. Choi, Y.J.; Beakes, G.; Glockling, S.; Kruse, J.; Nam, B.; Nigrelli, L.; Ploch, S.; Shin, H.D.; Shivas, R.G.; Telle, S.; et al. Towards a universal barcode of oomycetes-A comparison of the cox1 and cox2 loci. Mol. Ecol. Resour. 2015, 15, 1275-1288. [CrossRef]

215. Moorthie, S.; Mattocks, C.J.; Wright, C.F. Review of massively parallel DNA sequencing technologies. Hugo J. 2011, 5, 1-12. [CrossRef]

216. Férandon, C.; Xu, J.; Barroso, G. The $135 \mathrm{kbp}$ mitochondrial genome of Agaricus bisporus is the largest known eukaryotic reservoir of group I introns and plasmid-related sequences. Fungal Genet. Biol. 2013, 55, 85-91. [CrossRef]

217. Zhang, W.; Cui, H.; Wong, L.J.C. Comprehensive one-step molecular analyses of mitochondrial genome by massively parallel sequencing. Clin. Chem. 2012, 58, 1322-1331. [CrossRef]

218. Deiner, K.; Renshaw, M.A.; Li, Y.; Olds, B.P.; Lodge, D.M.; Pfrender, M.E. Long-range PCR allows sequencing of mitochondrial genomes from environmental DNA. Methods Ecol. Evol. 2017, 8, 1888-1898. [CrossRef]

219. Cameron, S.L. How to sequence and annotate insect mitochondrial genomes for systematic and comparative genomics research. Syst. Entomol. 2014, 39, 400-411. [CrossRef]

(C) 2020 by the authors. Licensee MDPI, Basel, Switzerland. This article is an open access article distributed under the terms and conditions of the Creative Commons Attribution (CC BY) license (http://creativecommons.org/licenses/by/4.0/). 